\title{
Neuroprotection by Caffeine in Hyperoxia-Induced Neonatal Brain Injury
}

\author{
Stefanie Endesfelder ${ }^{1, *}$, Ulrike Weichelt ${ }^{2}$, Evelyn Strauß ${ }^{1}$, Anja Schlör ${ }^{3}$, Marco Sifringer ${ }^{4}$, \\ Till Scheuer ${ }^{1}$, Christoph Bührer ${ }^{1}$ and Thomas Schmitz ${ }^{1}$ \\ 1 Department of Neonatology, Charité, Universitätsmedizin Berlin, 13353 Berlin, Germany; \\ evelyn.strauss@charite.de (E.S.); till.scheuer@charite.de (T.S.); christoph.buehrer@charite.de (C.B.); \\ thomas.schmitz@charite.de (T.S.) \\ 2 Department of Physiology, Charité, Universitätsmedizin Berlin, 10117 Berlin, Germany; \\ ulrike.weichelt@charite.de \\ 3 Department of Biochemistry and Biology, University of Potsdam, 14476 Potsdam, Germany; \\ anja.schloer@uni-potsdam.de \\ 4 Department of Anesthesiology and Intensive Care Medicine, Charité, Universitätsmedizin Berlin, 13353 \\ Berlin, Germany; marco.sifringer@charite.de \\ * Correspondence: stefanie.endesfelder@charite.de; Tel.: +49-30-450-559548; Fax: +49-30-450-559979
}

Academic Editors: Melpo Christofidou-Solomidou and Thomas J. Goodwin

Received: 14 November 2016; Accepted: 12 January 2017; Published: 18 January 2017

\begin{abstract}
Sequelae of prematurity triggered by oxidative stress and free radical-mediated tissue damage have coined the term "oxygen radical disease of prematurity". Caffeine, a potent free radical scavenger and adenosine receptor antagonist, reduces rates of brain damage in preterm infants. In the present study, we investigated the effects of caffeine on oxidative stress markers, anti-oxidative response, inflammation, redox-sensitive transcription factors, apoptosis, and extracellular matrix following the induction of hyperoxia in neonatal rats. The brain of a rat pups at postnatal Day 6 (P6) corresponds to that of a human fetal brain at 28-32 weeks gestation and the neonatal rat is an ideal model in which to investigate effects of oxidative stress and neuroprotection of caffeine on the developing brain. Six-day-old Wistar rats were pre-treated with caffeine and exposed to $80 \%$ oxygen for 24 and $48 \mathrm{~h}$. Caffeine reduced oxidative stress marker (heme oxygenase-1, lipid peroxidation, hydrogen peroxide, and glutamate-cysteine ligase catalytic subunit (GCLC)), promoted anti-oxidative response (superoxide dismutase, peroxiredoxin 1, and sulfiredoxin 1), down-regulated pro-inflammatory cytokines, modulated redox-sensitive transcription factor expression (Nrf2/Keap1, and NFkB), reduced pro-apoptotic effectors (poly (ADP-ribose) polymerase-1 (PARP-1), apoptosis inducing factor (AIF), and caspase-3), and diminished extracellular matrix degeneration (matrix metalloproteinases (MMP) 2, and inhibitor of metalloproteinase (TIMP) $1 / 2$ ). Our study affirms that caffeine is a pleiotropic neuroprotective drug in the developing brain due to its anti-oxidant, anti-inflammatory, and anti-apoptotic properties.
\end{abstract}

Keywords: anti-oxidative response; caffeine; hyperoxia; oxidative stress; preterm infants; developing brain

\section{Introduction}

Advances in neonatal intensive care have led to a significant increase in the survival rate of premature infants, but extremely premature infants have a higher risk of dying or suffering permanent and serious damage [1,2]. Up to $50 \%$ of surviving extremely preterm infants show cognitive deficits or behavioral problems during the later stages of development [3]. The sequelae of prematurity are described to be triggered by oxidative stress and free radical-mediated cell and tissue damage, leading to the term "oxygen radical disease of the prematurity" [4-6]. 
There are several reasons for the high susceptibility of preterm infants to oxidative damage: (i) birth is associated with a dramatic change of intrauterine hypoxic milieu to a relatively hyperoxic extrauterine environment, and this relative hyperoxia can be enhanced by supplemental oxygen $[7,8]$; (ii) premature infants are less able to cope with the oxygen-rich environment of extrauterine life because their antioxidant defense system is poorly developed [9]; and (iii) preterm infants have increased susceptibility to infections [5].

Oxidative stress can be defined as an imbalance between the amount of reactive oxygen species (ROS) and the intracellular and extracellular antioxidant protection systems. The antioxidative defense system undergoes developmental changes during the neonatal period, resulting in a relevantly lower intracellular defense in preterm infants compared to term infants [10].

In addition to the understanding of the pathology of oxidative stress and the associated effects on the development of premature infants, additional strategies must be developed. Recent studies have proposed that caffeine presents antioxidant activity and therefore, protects human against disorders associated with oxidative stress [11,12]. The methylxanthine caffeine is used as a first-line pharmacotherapy against apnoea in preterm infants [13]. Caffeine has a higher therapeutic index and a longer half-life compared to other methylxanthines. In addition, to the reduction of the frequency of apnoea, caffeine has additional short- and long-term effects $[14,15]$. As an adenosine receptor antagonist caffeine improves neonatal outcome, shows neuroprotective effects in the developing brain $[16,17]$, has anti-inflammatory effects $[18,19]$, decreases rates of bronchopulmonary dysplasia (BPD) and death [14,20], and shortens the duration of mechanical ventilation [14,21]. Side effects of caffeine have been described [22,23] to include tachycardia, higher oxygen consumption, and transient decrease of the growth rate in very low birth weight infants [24].

Up to date, it is not yet clarified whether caffeine can also act as a free radical scavenger. Shi et al. reported that caffeine may act as an antioxidant scavenger, thus explaining the observed anticarcinogenic properties of caffeine and related methylxanthine compounds [25]. Furthermore, caffeine prevented lipid peroxidation, reduced oxidative DNA damage [26], modulated oxidative stress in rat liver [27], and showed immunmodulatory effects under oxidative stress in the neonatal rat brain [16] and immune cells [28]. Due to the anti-oxidant properties per se and/or by the anti-inflammatory and anti-apoptotic effects of caffeine $[16,29,30]$, which seem to be adenosine receptor-mediated [30,31], caffeine would be a promising pleiotropic drug. Therefore, the aim of this in vivo study in a neonatal oxidative stress model was to investigate how caffeine affected the immature rodent brain against high oxygen exposure.

\section{Results}

\subsection{Hyperoxia Induces Oxidative Stress Which Is Counteracted by Caffeine}

Thiobarbituric acid reactive substances (TBARS) were increased in brain tissue of newborn rats exposed to $24 \mathrm{~h}$ of hyperoxia to $180 \% \pm 27.4 \%(p<0.01)$ compared to litter control mates kept in atmospheric air (Figure 1A). This was reduced by a single dose of caffeine $(77 \% \pm 11.8 \% ; p<0.001)$. In control animals, caffeine did not affect TBARS levels. Changes in TBARS after $48 \mathrm{~h}$ hyperoxia were not significant in comparison to matched normoxic litters. Interestingly, there was also a significant decrease in TBARS in normoxic newborn rats $48 \mathrm{~h}$ after the single administration of caffeine $(51 \% \pm 17.2 \% ; p<0.05)$.

To confirm the induction of oxidative stress by exposure to hyperoxia, we analyzed hydrogen peroxide concentrations through enzyme linked immunosorbent assay (ELISA) measurement in neonatal rodent brains after hyperoxia and normoxia with and without caffeine treatment (Figure 1B). Hyperoxia leads to a highly significant increase of hydrogen peroxide after $48 \mathrm{~h}$ exposure duration $(489 \% \pm 106.7 \% ; p<0.001)$ which was blocked by caffeine $(147 \% \pm 22.6 \% ; p<0.001)$. Treatment with caffeine in animals kept under normoxic conditions had no effect on hydrogen peroxide concentrations. 

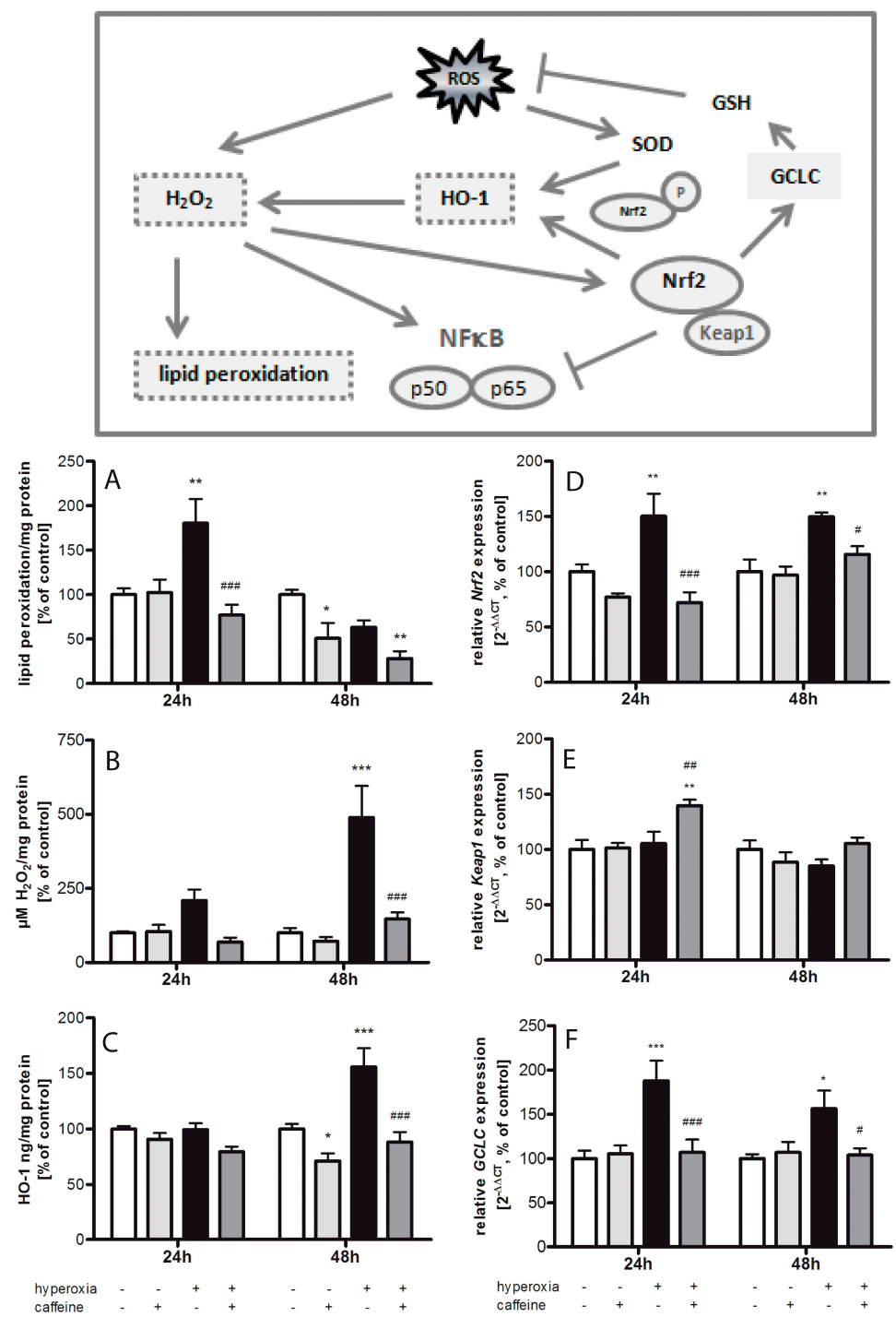

Figure 1. Caffeine reduces oxidative stress responses during exposure to hyperoxia. (Box) Reactive oxygen species imply hydrogen peroxide, which promotes lipid peroxidation. The antioxidant enzyme response is induced, which leads inter alia to an activation of heme oxigenase-1 (HO-1). The Nrf2-Keap1 system plays alongside the NFKB pathway an essential role in the implementation of the antioxidant gene regulation in response to oxidative stress. The catalytic subunit of glutamate-cysteine ligase (GCLC) is upregulated by Nrf2. Quantitation of brain homogenates by ELISA of: (A) TBARS/lipid peroxidation; (B) $\mathrm{H}_{2} \mathrm{O}_{2}$; and (C) HO-1; and mRNA expression by quantitative real-time PCR of: (D) Nrf2; (E) Keap1; and (F) GCLC. Groups are shown as normoxia (white bars), hyperoxia (black bars), with and without caffeine (dark grey and light grey bars, respectively) as mean \pm SEM, $n=4-5$ per group per time point. The $100 \%$ value is: (A) 1.268 and $1.959 \mu \mathrm{M} / \mathrm{mg}$ protein; (B) 0.887 and $2.946 \mu \mathrm{M} / \mathrm{mg}$ protein; (C) 3.604 and $2.891 \mathrm{ng} / \mathrm{mg}$ protein; (D) 1.008 and $1.029 C_{\mathrm{T}}$; (E) 1.014 and $1.029 C_{\mathrm{T}}$; and (F) 1.016 and $1.015 C_{\mathrm{T}}$ for 24 and $48 \mathrm{~h}$ groups, respectively. Data were analyzed by two-way ANOVA with Bonferroni post hoc test, with ${ }^{*} p<0.05,{ }^{* *} p<0.01$, and ${ }^{* * *} p<0.001$ versus control (atmospheric air), and ${ }^{\#} p<0.05$, ${ }^{\# \#} p<0.01$, and ${ }^{\# \#} p<0.001$ versus hyperoxia ( $80 \%$ oxygen without caffeine).

Heme oxigenase-1 (HO-1) protein levels were markedly increased in brain tissue after $48 \mathrm{~h}$ of hyperoxic stimulation $(156 \% \pm 16.8 \% ; p<0.001)$ compared with brain tissue from rats under normoxia (Figure 1C). Caffeine reduced the protein level significantly after $48 \mathrm{~h}$ hyperoxia $(88 \% \pm 8.9 \% ; p<0.001)$. HO-1 is not increased after $24 \mathrm{~h}$ hyperoxia. However, caffeine treatment reduced HO-1 levels after $48 \mathrm{~h}$ in control litters kept in room air $(71 \% \pm 15.6 \% ; p<0.05)$. 
NFE2-related factor 2 (Nrf2) (Figure 1D) was significantly induced both after $24 \mathrm{~h}(150 \% \pm 20.3 \%$; $p<0.01)$ and after $48 \mathrm{~h}(150 \% \pm 3.9 \% ; p<0.01)$ of hyperoxia, which was blocked by caffeine ( $24 \mathrm{~h}$ to $72 \% \pm 9.2 \% ; p<0.001$, and $48 \mathrm{~h}$ to $116 \% \pm 7.3 \% ; p<0.05$ ). Contrary to $N r f 2$, gene expression of Kelch-like ECH-associated protein 1 (Keap1; Figure 1E) was not affected by hyperoxia alone, but was significantly elevated by caffeine after $24 \mathrm{~h}$ exposure to hyperoxia $(140 \% \pm 5.3 \% ; p<0.01)$. Caffeine did not influence the expression of Keap1 at atmospheric air.

The glutamate-cysteine ligase (GCL) consists of two separate coded subunits, a catalytic (GCLC) and a modifier (GCLM), which catalyzes the rate-limiting phase of cellular antioxidant glutathione (GSH). GCLC (Figure 1F) mRNA expression was significantly induced both after $24 \mathrm{~h}(188 \% \pm 23.0 \%$; $p<0.001)$ and after $48 \mathrm{~h}(156 \% \pm 20.4 \% ; p<0.05)$ of hyperoxia, which were significantly reduced by caffeine $(24 \mathrm{~h}$ to $107 \% \pm 14.4 \% ; p<0.001$, and $48 \mathrm{~h}$ to $104 \% \pm 7.8 \% ; p<0.05)$. Single treatment with caffeine in animals kept under normoxic conditions had no effect on GCLC expression.

\subsection{Regulating Effect of Caffeine on the Imbalance of the Sulfiredoxin/Peroxiredoxin System after Hyperoxia}

Acute exposure to high oxygen leads to exhaustion of superoxide dismutases 3 (SOD3). SOD1 (Figure 2A) does reveal not statistically significant differences (at $24 \mathrm{~h} 66 \% \pm 5.4 \%$ and at $48 \mathrm{~h}$ $72 \% \pm 6.1 \%$ ), SOD2 (Figure $2 \mathrm{~B}$ ) to $63 \% \pm 7.2 \%$ at $24 \mathrm{~h}$, but SOD3 (Figure $2 \mathrm{C}$ ) was significantly reduced to $55 \% \pm 9.6 \%(p<0.05)$ at $24 \mathrm{~h}$. In comparison to hyperoxia without caffeine, we found significant increases for SOD1 to $111 \% \pm 14.4 \%(p<0.05)$ and $129 \% \pm 18.5 \%(p<0.01)$, for SOD3 to $159 \% \pm 13.1 \%$ $(p<0.001)$ and $171 \% \pm 19.3 \%(p<0.001)$ at $24 \mathrm{~h}$ and $48 \mathrm{~h}$, respectively, and for SOD2 to $217 \% \pm 25.5 \%$ $(p<0.001)$ at $48 \mathrm{~h}$. Under $48 \mathrm{~h}$ normoxic conditions, a single administration of caffeine leads to an increase of SOD2 $(188 \% \pm 23.3 \%, p<0.001)$ and SOD3 $(146 \% \pm 11.2 \%, p<0.05)$. Correspondingly, increasing peroxiredoxin (Prx) 1 and sulfiredoxin (Srx) 1 expression were observed at both time points. Prx1 protein expression (Figure 2D) was increased to $137 \% \pm 2.8 \%(p<0.001)$ at $24 \mathrm{~h}$ and to $145 \% \pm 6.2 \%(p<0.001)$ at $48 \mathrm{~h}$, and Srx1 protein expression (Figure $2 \mathrm{E})$ to $135 \% \pm 4.3 \%(p<0.001)$ and $150 \% \pm 9.3 \%(p<0.001)$, respectively. The administration of caffeine showed a significant decrease to $109 \% \pm 6.2 \%(p<0.01)$ and $75 \% \pm 5.9 \%(p<0.001)$ for Prx1, and to $99 \% \pm 8.7 \%(p<0.001)$ and $104 \% \pm 9.3 \%(p<0.001)$ for Srx1 to both times examined. Interestingly, there was a reduction in Prx1 at $48 \mathrm{~h}$ under normoxia to $56 \% \pm 2.6 \%(p<0.001)$ and an increase of protein expression after $24 \mathrm{~h}$ under normoxia to $126 \% \pm 3.6 \%(p<0.01)$.
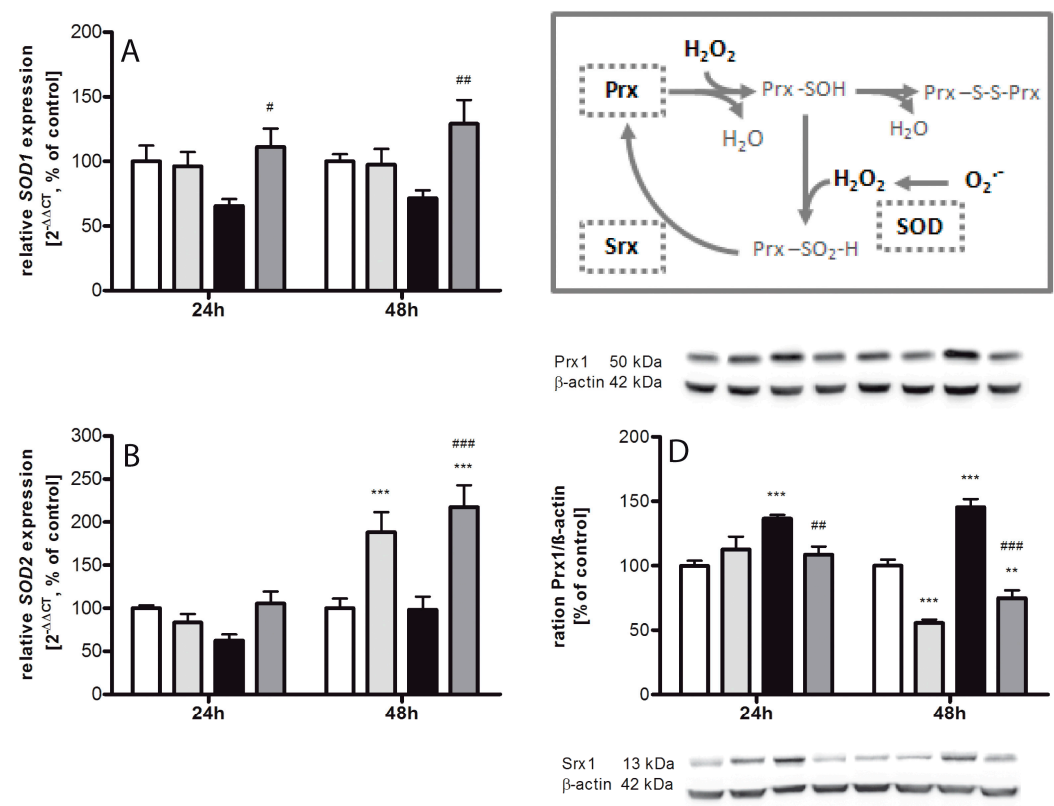

Figure 2. Cont. 

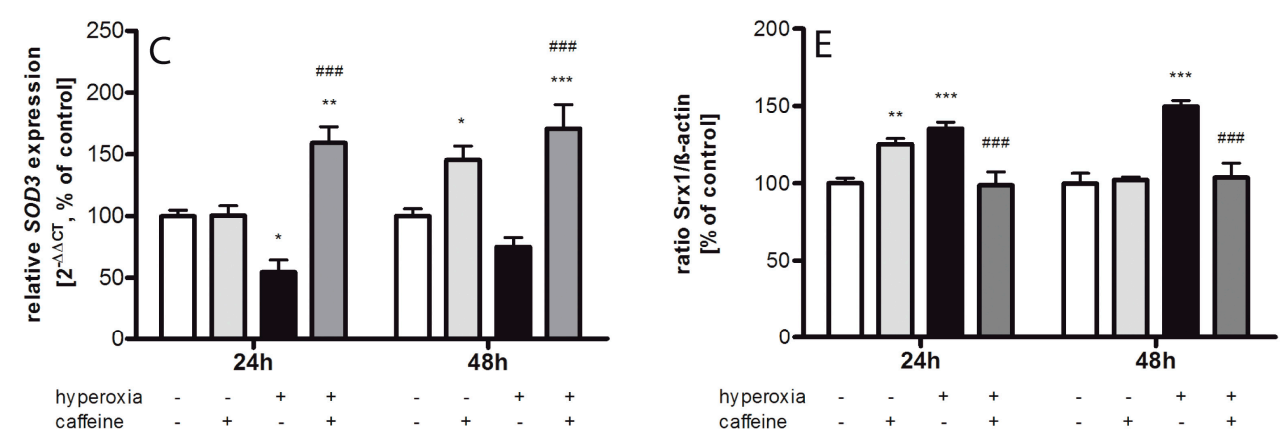

Figure 2. Caffeine modulates antioxidative enzymes. (Box) The high production of ROS under oxidative stress requires the existence of a set of ROS scavenger mechanisms. These are firstly, the group of superoxide dismutase (SOD), which are not only able to scavenge ROS but also repair cell damage and possibly serve as redox sensors, and secondly, the thiol-based antioxidants peroxiredoxin (Prx) as well as sulfiredoxin (Srx), which are major internal housekeeping antioxidant molecules that act as redox switches to modulate homeostasis. SOD isoform mRNA expression was analyzed in brain homogenates. Quantification of mRNA expression by quantitative real-time PCR of: (A) SOD1; (B) SOD2; and (C) SOD3; and protein expression measured by Western blot of: (D) Prx1; and (E) Srx1. Groups are shown as normoxia (white bars), hyperoxia (black bars), with and without caffeine (dark grey and light grey bars, respectively) as mean \pm SEM, $n=4-5$ per group per time point. The $100 \%$ value is: (A) 1.031 and $1.006 C_{\mathrm{T}}$; (B) 1.002 and $1.025 C_{\mathrm{T}} ;(\mathbf{C}) 1.005$ and $1.007 C_{\mathrm{T}}$; (D) 0.87 and 0.61 ratio intensity $/ \mathrm{mm}^{2}$; and (E) 0.39 and 0.67 ratio intensity $/ \mathrm{mm}^{2}$, for $24 \mathrm{~h}$ and $48 \mathrm{~h}$ groups, respectively. Data were analyzed by two-way ANOVA with Bonferroni post hoc test, with * $p<0.05$, ** $p<0.01$, and ${ }^{* * *} p<0.001$ versus control (atmospheric air), and ${ }^{\#} p<0.05,{ }^{\# \#} p<0.01$, and ${ }^{\# \# \#} p<0.001$ versus hyperoxia ( $80 \%$ oxygen without caffeine).

\subsection{Effects of Caffeine on the Inflammatory Cytokine Expression}

The cerebral neuro-inflammatory response in our neonatal oxidative stress model was analyzed by measuring changes in cytokine production and inducible nitric oxide synthase (iNOS) in the brain. Using qPCR for gene expression and ELISA for protein expression analysis, we determined levels of tumor necrosis factor $\alpha(\mathrm{TNF} \alpha)$, interleukin (IL)-1 $\beta$, interferon $\gamma(\mathrm{IFN} \gamma)$, and IL-18 as pro-inflammatory cytokines, IL-12 as early pro- and late anti-inflammatory cytokine, and iNOS. Overall, significant differences between normoxia control group and the hyperoxia group were detected for all cytokines at 24 and/or $48 \mathrm{~h}$ (Figure 3).

Oxidative stress is usually thought to be responsible for tissue injury associated with a range of brain injury, inflammation, and degenerative processes. Moreover, inflammatory target proteins, including iNOS, are associated with oxidative stress induced by pro-inflammatory factors such as cytokines. Expression of iNOS (Figure 3A) was significantly increased by $24 \mathrm{~h}$ hyperoxia $(179 \% \pm 32.1 \% ; p<0.01)$, and significantly decreased at $48 \mathrm{~h}(49 \% \pm 4.5 \% ; p<0.05)$, which was blocked by caffeine at $24 \mathrm{~h}(100 \% \pm 8.0 \% ; p<0.01)$.

In response to brain injury by hyperoxia, $\mathrm{TNF} \alpha$ production is rapidly increased. An increase of TNF $\alpha$ mRNA $(127 \% \pm 4.8 \% ; p<0.05)$ was found after $24 \mathrm{~h}$ of hyperoxia (Figure 3B). After $48 \mathrm{~h}$ of hyperoxia, the increase in protein expression of $\mathrm{TNF} \alpha$ (Figure 3C) was largely pronounced $(251 \% \pm 50.8 \% ; p<0.001)$. The administration of caffeine drastically reduced TNF $\alpha$ mRNA expression under hyperoxic conditions at $24 \mathrm{~h}(31 \% \pm 5.2 \% ; p<0.001)$ and at $48 \mathrm{~h}(51 \% \pm 5.5 \% ; p<0.01)$, which was also observed under normoxic conditions (at $24 \mathrm{~h} 40 \% \pm 7.6 \%$; $p<0.001 ;$ at $48 \mathrm{~h} 57 \% \pm 5.1 \%$; $p<0.001)$. On translational protein levels, caffeine caused a marked reduction in the expression of $\mathrm{TNF} \alpha$ protein at $48 \mathrm{~h}$ (from $251 \% \pm 50.8 \%$ to $110 \% \pm 21.7 \% ; p<0.001$ ). However, TNF $\alpha$ protein was not affected by caffeine in newborn rats kept at atmospheric air (Figure 3C). 

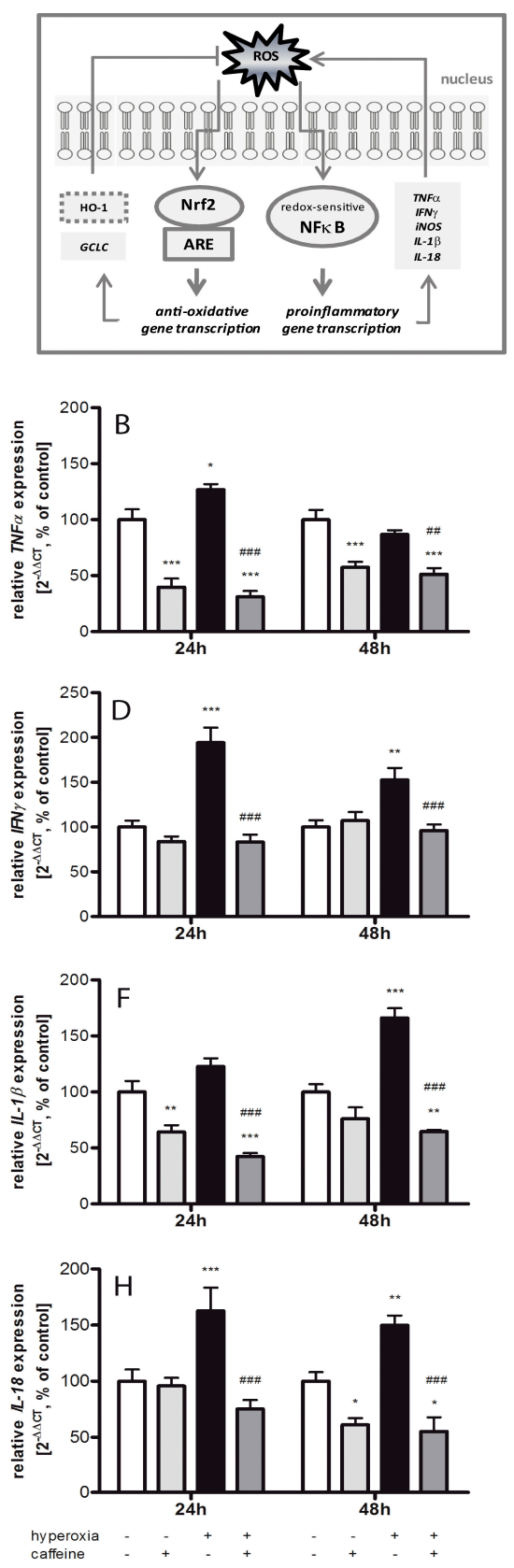
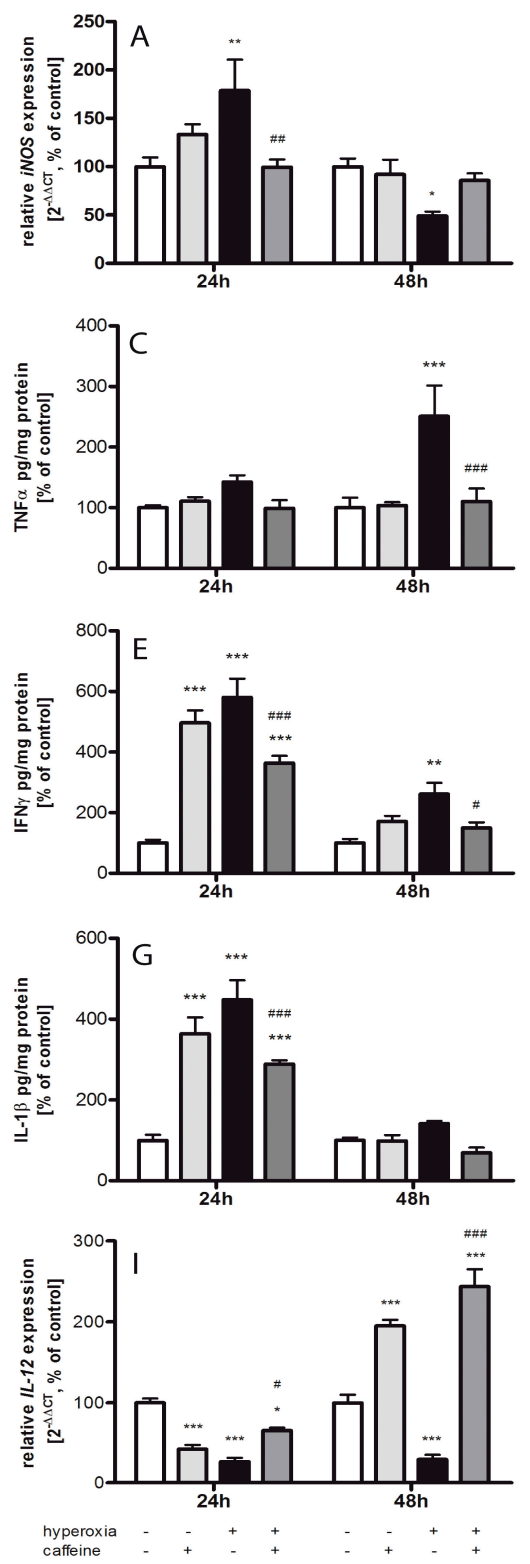

Figure 3. Changes in the expression of cytokines and iNOS in neonatal rat brains after hyperoxic injury with and without caffeine. (Box) Nrf2 activation promotes the expression of anti-oxidative gene transcription and reduces oxidative stress-induced inflammatory activation by blocking the redox-sensitive NFKB pathway (ARE; antioxidant response element). The protein concentration ( $\mathrm{pg} / \mathrm{mg}$ protein) and relative mRNA expression of cytokines were measured in brain homogenates from normoxia (white bars), caffeine with normoxia (light grey bars), hyperoxia (black bars), and hyperoxia with caffeine (dark grey bars) by ELISA assay and quantitative real-time PCR of: (A) iNOS; $(\mathbf{B}, \mathbf{C}) \mathrm{TNF} \alpha ;(\mathbf{D}, \mathrm{E}) \mathrm{IFN} \gamma ;(\mathbf{F}, \mathbf{G}) \mathrm{IL}-1 \beta ;(\mathbf{H}) \mathrm{IL}-18$; and $(\mathbf{I}) \mathrm{IL}-12$. Data are shown as mean $\pm \mathrm{SEM}$, $n=4-5$ per group per time point. The $100 \%$ value is: (A) 1.016 and $1.015 C_{\mathrm{T}}$; (B) 1.021 and $1.018 C_{\mathrm{T}}$; (C) 21.22 and $29.19 \mathrm{pg} / \mathrm{mg}$ protein; (D) 1.012 and $1.013 \mathrm{C}_{\mathrm{T}}$; (E) 1.701 and $2.121 \mathrm{pg} / \mathrm{mg}$ protein; (F) 1.021 and $1.010 C_{\mathrm{T}}$; (G) 16.58 and $8.37 \mathrm{pg} / \mathrm{mg}$ protein; (H) 1.026 and $1.016 C_{\mathrm{T}}$; and (I) 1.006 and $1.019 C_{\mathrm{T}}$ for 24 and $48 \mathrm{~h}$ groups, respectively. Data were analyzed by two-way ANOVA with Bonferroni post hoc test, with ${ }^{*} p<0.05,{ }^{* *} p<0.01$, and ${ }^{* * *} p<0.001$ versus control (atmospheric air), and ${ }^{\#} p<0.05$, $\#$ \# $p<0.01$, and ${ }^{\# \#} p<0.001$ versus hyperoxia (80\% oxygen without caffeine). 
In relation to the cytokines measured in these experiments, IFN $\gamma$ showed the largest changes in mRNA and protein levels in the hyperoxic brain (Figure 3D,E). A significant increase was observed after $24 \mathrm{~h}$ (mRNA $194 \% \pm 16.8 \%, p<0.001$; protein $580 \% \pm 61.6 \%, p<0.001$ ) and $48 \mathrm{~h}$ (mRNA $153 \% \pm 13.3 \%$, $p<0.01$; protein $262 \% \pm 36.7 \%, p<0.01$ ) of hyperoxia exposure. A single dose of caffeine diminished this expression at both time points. At 24 and $48 \mathrm{~h}$, there is a significant reduction in protein expression to $363 \% \pm 24.1 \%(p<0.001)$ and to $150 \% \pm 18.5 \%(p<0.05)$, respectively. Similarly, caffeine affects under hyperoxia IFN $\gamma$ on the mRNA level with an attenuation to $83 \% \pm 8.3 \%(p<0.001)$ after $24 \mathrm{~h}$ and $96 \% \pm 6.8 \%(p<0.001)$ after $48 \mathrm{~h}$. Remarkably, administration of caffeine in control animals showed a high increase of the IFN $\gamma$ protein expression at $24 \mathrm{~h}(497 \% \pm 40.8 \% ; p<0.001)$ compared to untreated control litters, whereas no changes were observed at the mRNA level.

As a further indication of pro-inflammatory responses, $24 \mathrm{~h}$ hyperoxia caused a large increase of IL-1 $\beta$ protein expression $(448 \% \pm 48.6 \% ; p<0.001)$ as compared to controls (Figure 3F,G). The application of caffeine in hyperoxic animal led to a reduction of IL-1 $\beta$ protein (at $24 \mathrm{~h} 289 \% \pm 9.4 \%$; $p<0.001)$. Caffeine administration alone under normoxia also showed a dramatic increase in the protein level after $24 \mathrm{~h}(363 \% \pm 40.5 \% ; p<0.001)$. The mRNA expression significantly decreased during normoxia and caffeine administration after $24 \mathrm{~h}(64 \% \pm 5.9 \% ; p<0.01)$. Hyperoxia exposure resulted in a non-significant increase $(122 \% \pm 7.4 \%)$ at $24 \mathrm{~h}$, and a significant increase after $48 \mathrm{~h}$ hyperoxia exposure $(166 \% \pm 8.7 \% ; p<0.001)$. Here also, mRNA expression under hyperoxia is significantly reduced below the normoxic level by caffeine administration at $24 \mathrm{~h}(42 \% \pm 3.2 \% ; p<0.001)$ and $48 \mathrm{~h}$ $(65 \% \pm 1.7 \% ; p<0.001)$.

Exposure to hyperoxia increased the concentration of $I L-18$ mRNA at $24 \mathrm{~h}$ to $163 \% \pm 20.6 \%$ $(p<0.001)$ and $48 \mathrm{~h}$ to $150 \% \pm 8.6 \%(p<0.01)$ compared with rat pups exposed to normoxia (Figure $3 \mathrm{H})$. The application of caffeine significantly reduced cytokine level below hyperoxia at both time points to $72 \% \pm 7.9 \%(p<0.001)$ and to $55 \% \pm 12.6 \%(p<0.001)$, respectively. Caffeine under non-hyperoxic conditions resulted in a significant reduction in IL-18 expression at $48 \mathrm{~h}(61 \% \pm 5.9 \% ; p<0.05)$.

Interestingly, a drastic reduction in IL-12 mRNA expression (Figure 3I; $28 \% \pm 4.7 \%$; $p<0.001$, and $30 \% \pm 5.7 \% ; p<0.001$ ) is detected after 24 and $48 \mathrm{~h}$ of hyperoxia, respectively. Under hyperoxia exposure with prior application of caffeine, the expression increased significantly at $24 \mathrm{~h}$ at $66 \% \pm 3.6 \%$ $(p<0.05)$ and at $48 \mathrm{~h}$ at $244 \% \pm 21.5 \%(p<0.001)$. In contrast, the expression of $I L-12$ under normoxia with caffeine was reduced after $24 \mathrm{~h}(43 \% \pm 5.3 \% ; p<0.001)$ and increased after $48 \mathrm{~h}$ $(195 \% \pm 7.5 \% ; p<0.001)$.

\subsection{Hyperoxia Modulates Gene Expression of Transcription Factors and Caffeine Counteracts}

As shown in Figure 4A the nuclear factor of kappa light polypeptide gene enhancer in B-cells $(\mathrm{NF \kappa B})$ protein expression was increased by caffeine under normoxia/hyperoxia at $24 \mathrm{~h}(237 \% \pm 25.8 \%$; $p<0.001$, and $204 \% \pm 36.7 \% ; p<0.001$, respectively) and at $48 \mathrm{~h}(200 \% \pm 6.0 \% ; p<0.01)$ in the cytosol compared to the control group. There were no changes under hyperoxic exposure alone, while the alteration in protein level in the nucleus indicated an up-regulation of NFkB under hyperoxic condition at both time points $(224 \% \pm 31.9 \% ; p<0.001$, and $334 \% \pm 36.3 \% ; p<0.001$, respectively). In the nuclear protein fraction, a single dose of caffeine significantly reduced NFkB expression at $24 \mathrm{~h}$ to $114 \% \pm 20.8 \%(p<0.001)$, and at $48 \mathrm{~h}$ to $74 \% \pm 4.1 \%(p<0.001)$.

The mRNA expression ratios of $N F \kappa B 1$ and $N F \kappa B 2$ corresponded with the cytosolic protein data (Figure 4B,C). Here we showed that hyperoxia resulted in an mRNA reduction of both $N F \kappa B$ forms (NFKB1 and 2) at both time points. Caffeine with hyperoxia exposure always led to an increase in mRNA expression (NFkB1 at $24 \mathrm{~h}$ from $75 \% \pm 6.5 \%$ to $154 \% \pm 11.3 \%(p<0.001)$, and at $48 \mathrm{~h}$ from $68 \% \pm 6.1 \%$ to $115 \% \pm 4.7 \%(p<0.01) ; N F \kappa B 2$ at $24 \mathrm{~h}$ from $72 \% \pm 4.0 \%$ to $114 \% \pm 12.1 \%(p<0.01)$, and at $48 \mathrm{~h}$ from $38 \% \pm 3.5 \%$ to $79 \% \pm 7.7 \%(p<0.01))$. NF $\kappa B 1$ expression was bolstered by caffeine under normoxia after $24 \mathrm{~h}(142 \% \pm 6.8 \% ; p<0.01)$. 

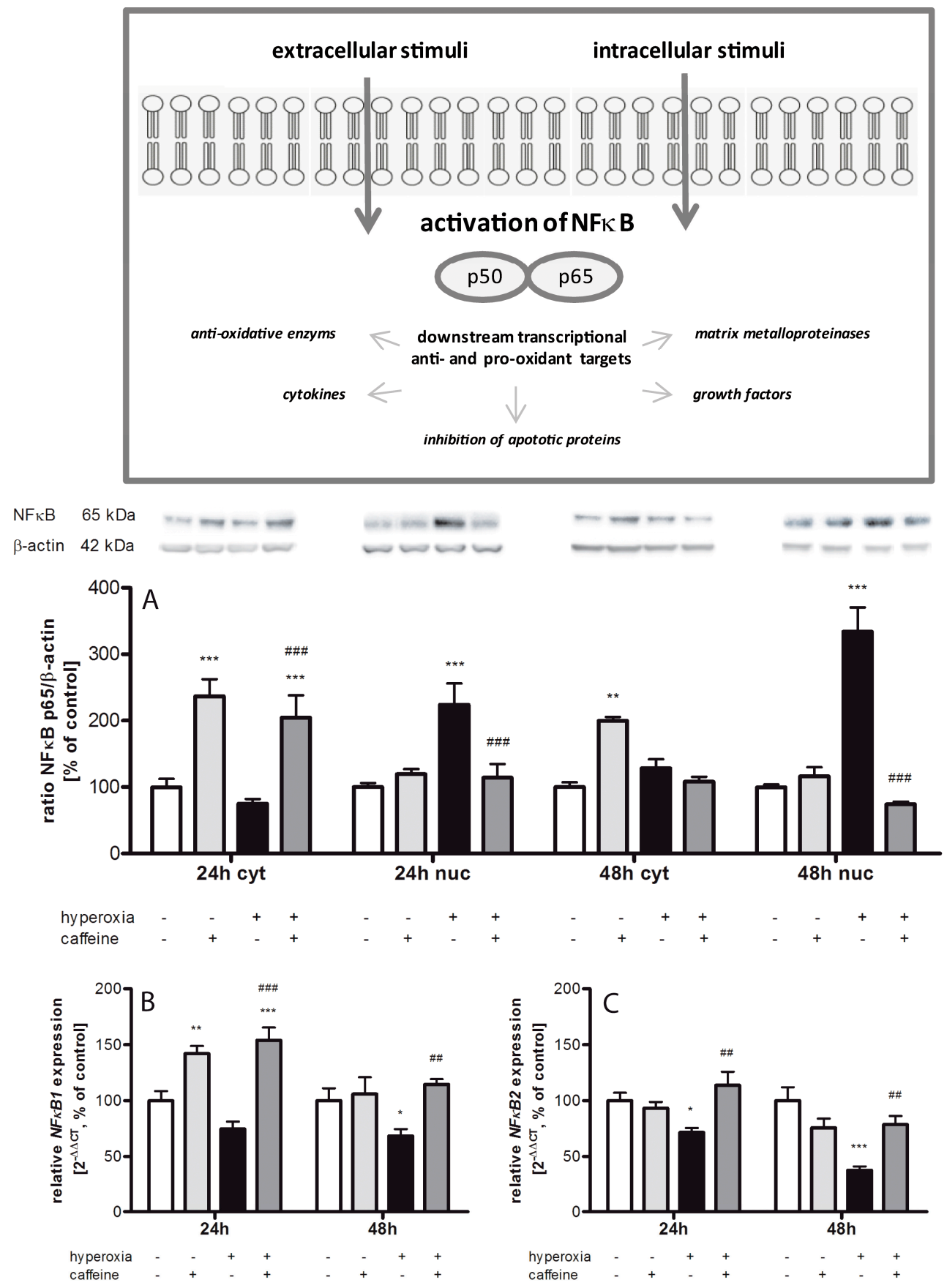

Figure 4. NFkB expression is affected by caffeine administration. (Box) Stimulation of the NFkB pathway is mediated by diverse signal transduction cascades. The change of protein expression of NFKB were measured in brain homogenates of normoxia (white bars), caffeine with normoxia (light grey bars), hyperoxia (black bars), and hyperoxia with caffeine (dark grey bars) by Western blot and quantitative real-time PCR with: (A) NFKB protein expression in cytosolic (cyt) and nuclear (nuc) fraction; and (B,C) NFKB mRNA expression after $24 \mathrm{~h}$ and $48 \mathrm{~h}$ of oxygen exposure. Data are shown as mean \pm SEM, $n=5$ per group per time point. The $100 \%$ value is: (A) (cyt) 0.035 and 0.024 ratio intensity $/ \mathrm{mm}^{2}$ and (nuc) 0.092 and 0.127 ratio intensity $/ \mathrm{mm}^{2}$; (B) 1.017 and $1.028 C_{\mathrm{T}}$; and (C) 1.010 and $1.032 C_{\mathrm{T}}$ for 24 and $48 \mathrm{~h}$ groups, respectively. Data were analyzed by two-way ANOVA with Bonferroni post hoc test, with ${ }^{*} p<0.05,{ }^{* *} p<0.01$, and ${ }^{* * *} p<0.001$ versus control (atmospheric air), and ${ }^{\# \#} p<0.01$ and ${ }^{\# \#} p<0.001$ versus hyperoxia (80\% oxygen without caffeine). 


\subsection{Caffeine Prevents Hyperoxia-Mediated Increase in Apoptotic Gene Expression}

We measured the cytosolic and nuclear expression of cleaved poly (ADP-ribose) polymerase-1 (PARP-1) (Figure 5A). Hyperoxia increased nuclear PARP-1 at both times measured (24 h with $200 \% \pm 24.3 \% ; p<0.001 ; 48 \mathrm{~h}$ with $188 \% \pm 14.5 \% ; p<0.001$ ) and no changes observed in cytosolic fraction. Caffeine reduced this increase to the normoxic level $(p<0.001)$. High oxygen also induced cytosolic apoptosis inducing factor (AIF) protein at $24 \mathrm{~h}$ (Figure $5 \mathrm{~B} ; 145 \% \pm 4.9 \% ; p<0.001$ ), increased caspase-3 cleavage (Figure $5 \mathrm{C})$ at $24 \mathrm{~h}(143 \% \pm 12.3 \% ; p<0.001)$ and at $48 \mathrm{~h}(133 \% \pm 6.0 \%$; $p<0.01$ ), and enhanced caspase-3 mRNA expression at $24 \mathrm{~h}$ (Figure 5D; $159 \% \pm 9.0 \% ; p<0.001$ ). For the targets investigated, the application of caffeine resulted in a significant reduction of protein and/or mRNA expression (AIF at $24 \mathrm{~h}$ from $145 \% \pm 4.9 \%$ to $103 \% \pm 4.6 \%(p<0.001)$; cleaved caspase- 3 at $24 \mathrm{~h}$ from $143 \% \pm 12.3 \%$ to $91 \% \pm 5.6 \%(p<0.001)$, and at $48 \mathrm{~h}$ from $133 \% \pm 6.0 \%$ to $109 \% \pm 2.0 \%(p<0.05)$; caspase- 3 mRNA expression at $24 \mathrm{~h}$ from $159 \% \pm 9.0 \%$ to $108 \% \pm 3.7 \%(p<0.001)$, and at $48 \mathrm{~h}$ from to $74 \% \pm 2.6 \%(p<0.05))$.

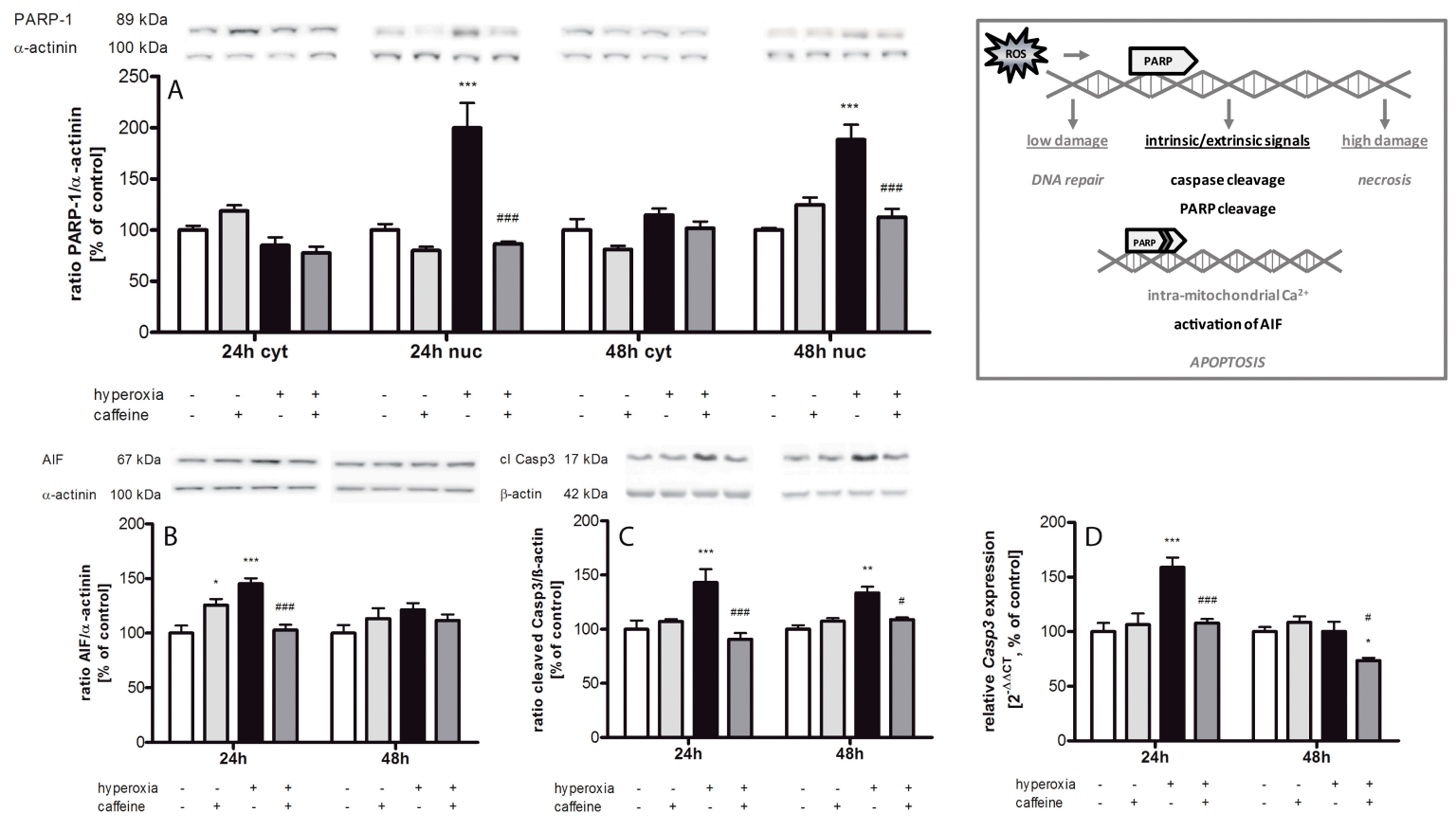

Figure 5. Caffeine inhibits hyperoxia-induced apoptotic key mediators. (Box) ROS-induced DNA damage activated PARP-1, an initially repair enzyme. PARP-1 is a substrate of caspase-3, a member of a highly specialized family of cysteinyl-aspartate proteases (caspases) involved in apoptosis. Upon cleavage and progression of cell death intramitochondrial calcium is released and AIF is induced. Analysis of the expression of apoptotic mediators were conducted in cytosolic (cyt) and nuclear (nuc) protein fraction and relative mRNA expression was measured in brain homogenates of normoxia (white bars), caffeine with normoxia (light grey bars), hyperoxia (black bars), and hyperoxia with caffeine (dark grey bars) by Western blot and quantitative real-time PCR with protein expression of: (A) cleaved PARP-1 (cyt and nuc); (B) AIF (cyt); and (C) cleaved caspase-3 (cyt); and mRNA expression of (D) caspase-3. Data are shown as mean \pm SEM, $n=5$ per group per time point. The $100 \%$ value is: (A) (cyt) 0.051 and 0.760 ratio intensity $/ \mathrm{mm}^{2}$ and (nuc) 0.064 and 0.043 ratio intensity $/ \mathrm{mm}^{2}$; (B) 0.216 and 0.309 ratio intensity $/ \mathrm{mm}^{2}$; (C) 0.691 and 0.823 ratio intensity $/ \mathrm{mm}^{2}$; and (D) 1.014 and $1.004 \mathrm{C}_{\mathrm{T}}$ for $24 \mathrm{~h}$ and $48 \mathrm{~h}$ groups, respectively. Data were analyzed by two-way ANOVA with Bonferroni post hoc test, with ${ }^{*} p<0.05,{ }^{* *} p<0.01$, and ${ }^{* * *} p<0.001$ versus control (atmospheric air), and ${ }^{\#} p<0.05$, and ${ }^{\# \# \#} p<0.001$ versus hyperoxia (80\% oxygen without caffeine). 


\subsection{Caffeine Effects on Matrix Metalloproteinases and the tPa/Plasminogen System}

Gel gelatin zymography was used to investigate the effect of oxidative stress and caffeine on the gelatinases expressions (Figure 6A). In the hyperoxic group a reduced level of pro-matrix metalloproteinases (MMP) $2(72 \mathrm{kDa})$ was detected at $24 \mathrm{~h}(64 \% \pm 3.1 \% ; p<0.001)$. After $48 \mathrm{~h}$ hyperoxia pro-MMP2 was increased $(141 \% \pm 2.2 \% ; p<0.001)$ and significantly decreased with caffeine application $(79 \% \pm 1.9 \% ; p<0.001)$. Caffeine alone under normoxic exposure showed a higher level on pro-MMP2 after $24 \mathrm{~h}(157 \% \pm 5.6 \% ; p<0.001)$ and a lower level after $48 \mathrm{~h}(75 \% \pm 1.2 \% ; p<0.001)$. At both time points acute hyperoxia exposure led to a drastic increase of active MMP2 (24 h with $281 \% \pm 11.9 \% ; p<0.001 ; 48 \mathrm{~h}$ with $157 \% \pm 3.7 \% ; p<0.001)$, which was again mitigated by caffeine ( $24 \mathrm{~h}$ to $211 \% \pm 3.2 \% ; p<0.001 ; 48 \mathrm{~h}$ to $51 \% \pm 1.0 \% ; p<0.001$ ). Caffeine application at normoxia reduced the processing of active MMP2 $(24 \mathrm{~h}$ to $76 \% \pm 1.8 \% ; p<0.001 ; 48 \mathrm{~h}$ to $75 \% \pm 1.2 \% ; p<0.001$ ). Contrary to MMP2, no active MMP9 band was detected in any samples.
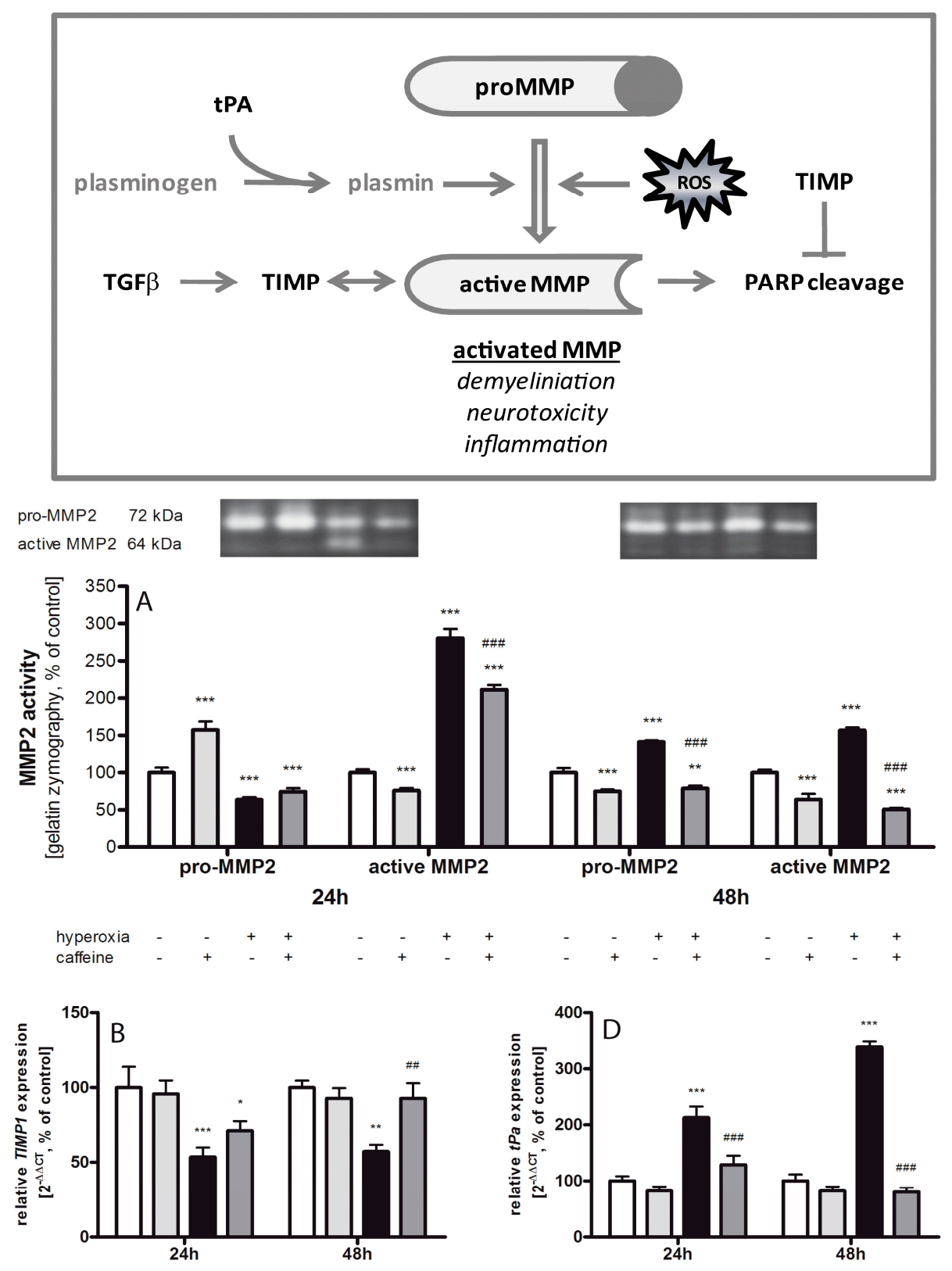

Figure 6. Cont. 

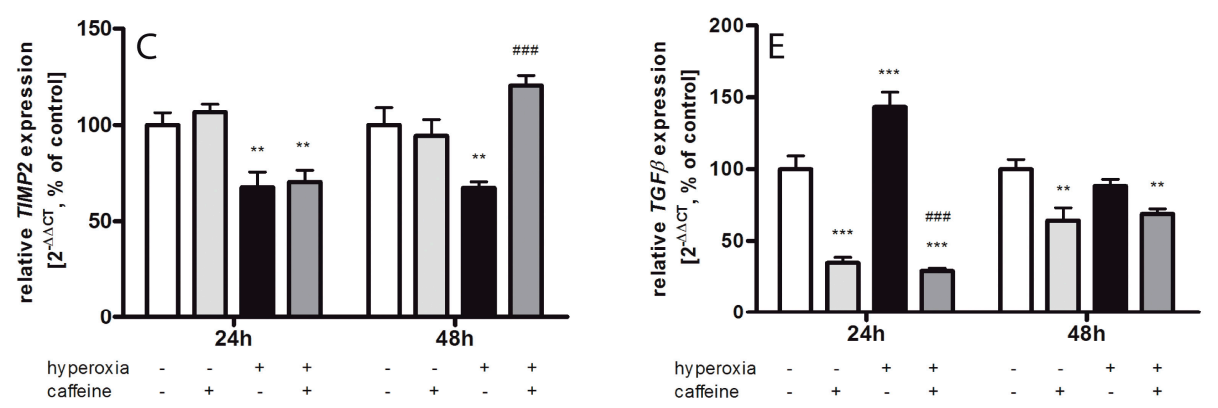

Figure 6. Hyperoxia-mediated imbalance in the MMP-TIMP system counteracted by caffeine. (Box) The matrix metalloproteinase (MMP) system can be activated via the plasminogen/plasmin system, and ROS. Active MMPs affect a variety of extracellular and immune regulatory proteins and are involved in modulating and degrading processes. Active MMPs can be inhibited by tissue inhibitors of metalloproteinases (TIMPs). TGF- $\beta$ can enhance the expression of MMPs and TIMPs. MMP2 and MMP9 are able to cleave PARP-1. The MMP inhibitor TIMP2 is able to block PARP-1 degradation. The pro and active MMPs were analyzed with gelatin zymography and relative mRNA expression were measured in brain homogenates of normoxia (white bars), caffeine with normoxia (light grey bars), hyperoxia (black bars), and hyperoxia with caffeine (dark grey bars) by quantitative real-time PCR of: (A) pro/active MMP2; (B,C) TIMP1/2 mRNA; (D) tissue plasminogen activator ( $\mathrm{Pa}$ ) mRNA; and (E) TGF- $\beta$ mRNA. Data are shown as mean \pm SEM, $n=4$ (for gelatin zymography)- 5 per group per time point. The $100 \%$ value is (A) (pro) $7.849 \times 10^{6}$ and $0.949 \times 10^{6}$ intensity $/ \mathrm{mm}^{2}$ and (active) $11.18 \times 10^{6}$ and $0.731 \times 10^{6}$ intensity $/ \mathrm{mm}^{2} ;\left(\right.$ B) 1.043 and $1.004 C_{\mathrm{T}} ;(\mathrm{C}) 1.008$ and $1.017 C_{\mathrm{T}}$; (D) 1.013 and $1.026 C_{\mathrm{T}}$; and (E) 1.018 and $1.010 C_{\mathrm{T}}$ for 24 and $48 \mathrm{~h}$ groups, respectively. Data were analyzed by two-way ANOVA with Bonferroni post hoc test, with ${ }^{*} p<0.05,{ }^{* *} p<0.01$, and ${ }^{* * *} p<0.001$ versus control (atmospheric air), and ${ }^{\# \#} p<0.01$ and ${ }^{\# \#} p<0.001$ versus hyperoxia (80\% oxygen without caffeine).

The inhibitors of these metalloproteinases, especially tissue inhibitor of metalloproteinase (TIMP) 1/2 (Figure 6B,C), are down-regulated at $24 \mathrm{~h}$ (TIMP1: 54\% \pm 6.5\%; $p<0.001 ;$ TIMP2: 68\% $\pm 7.9 \%$; $p<0.01)$ and $48 \mathrm{~h}($ TIMP1: 57\% $\pm 4.6 \% ; p<0.01 ;$ TIMP2: 67\% $\pm 3.2 \% ; p<0.01)$. Caffeine increased the mRNA expression of both inhibitors only at $48 \mathrm{~h}$ (TIMP1: 93\% $\pm 10.2 \% ; p<0.01 ;$ TIMP2: $121 \% \pm 5.2 \%$; $p<0.001)$. Caffeine alone had no significant influence. The tissue plasminogen activator (tPa) generates the active protease, plasmin, which is capable of degrading numerous substrates. Here (Figure 6D), hyperoxia led to a strong increase of $t \mathrm{~Pa}$ mRNA expression $(24 \mathrm{~h}$ to $213 \% \pm 19.9 \% ; p<0.001 ; 48 \mathrm{~h}$ to $339 \% \pm 9.6 \% ; p<0.001)$ and a single dose of caffeine reduced $t P a$ to normoxia level (24 $\mathrm{h}$ to $129 \% \pm 16.6 \% ; p<0.001 ; 48 \mathrm{~h}$ to $80 \% \pm 7.5 \% ; p<0.001)$.

The gene expression of transforming growth factor-(TGF)- $\beta$ (Figure 6E) is highly increased after $24 \mathrm{~h}(143 \% \pm 10.4 \% ; p<0.001)$ of hyperoxia. Caffeine strongly reduced TGF- $\beta$ mRNA under normoxia ( $24 \mathrm{~h}$ to $35 \% \pm 3.8 \% ; p<0.001 ; 48 \mathrm{~h}$ to $64 \% \pm 8.8 \% ; p<0.01$ ) as compared to control, as well as hyperoxic conditions compared to the hyperoxic group without caffeine ( 24 h to $29 \% \pm 1.9 \% ; p<0.001$; $48 \mathrm{~h}$ to $69 \% \pm 3.6 \% ; p<0.01$ ) at both time points.

\section{Discussion}

Neuronal injury and neurological maldevelopment in preterm infants is commonly ascribed to perinatal infection/inflammation and to oxidative stress hitting the immature brain at a vulnerable phase of development. In our neonatal rat model, oxidative stress is induced by early exposure to high oxygen levels for 24 and $48 \mathrm{~h}$, in which neural cell injury has been shown to occur in a way that is comparable to the human neonatal situation [32].

In preterm infants, caffeine is used to stimulate breathing activity and prevent the onset of apnoea [24]. Based on some clinical studies, benefits of caffeine administration for the neurological outcome of preterm infants have been suggested [13,14,21,24]. To date, the mechanisms of 
neuroprotection afforded by caffeine are under investigated. Our study of the neonatal oxidative stress model elucidate that a single dose of caffeine in an acute hyperoxia model effectively inhibits pro-inflammatory cytokine production and pro-apoptotic effectors, modulates anti-oxidative enzymes, and affects components of the extracellular matrix.

\subsection{Oxidative Stress Response}

Oxidative stress is caused by excess of free radical formation and/or an overproduction of ROS, and is a major factor of injury in the developing brain leading to neurological sequelae of preterm birth [33,34]. In our study in six-day-old hyperoxia-exposed rats, oxidative stress was found to be caused by an increase in hydrogen peroxide, a reactive oxygen metabolic product and a major regulator of oxidative stress-related processes, and of the stress response protein HO-1, which confers protection against a variety of oxidant-induced cell and tissue injury [35], leading to an increase in lipid peroxidation [36].

The increased HO-1 expression suggests an activation of protective mechanisms in response to unwanted cellular oxidative conditions [35]. Anti-oxidative enzymes, such as glutathione peroxidase, catalase, and SODs are essential to preserving cells from exposure to oxidative damage [37]. SOD converts superoxide into hydrogen peroxide and oxygen, with hydrogen peroxide being less toxic. Several studies have demonstrated increases in oxidative stress markers after exposure to hyperoxia in animals and humans [4,38]. Changes in the gene expression and enzymatic activity of SODs have been characterized in the rodent brain as a consequence of aging, oxygen, or pro-oxidant drug exposure [39]. Our results revealed a drastic oxygen-induced reduction in SOD3 transcript in newborn rat brains. These findings are contrary to previous studies which showed an oxidative stress-induced up-regulation of the SOD transcript, but SOD activity was unaffected [37].

Nrf2 is a redox-sensitive transcription factor that mediates protection against oxidative stress via the transcriptional activation of several antioxidant enzymes through the antioxidant response element (ARE). Nrf2 is negatively regulated by Keap1 thereby providing inducible antioxidant defense. Under basal conditions Nrf2 is regulated by Keap1, but under oxidative stress, the Nrf2 pathways can also be regulated independently of Keap1 [40]. The experimentally determined Nrf2 mRNA increase confirms the induction of antioxidant genes under hyperoxic conditions while the expression of Keap1 is unchanged.

Glutathione (GSH) plays an important role for antioxidant defense and for the regulation of intracellular redox homeostasis. The rate-limiting step of cellular antioxidant GSH is catalyzed by glutamate-cysteine ligase (GCL), which consists of a catalytic (GCLC) and a modifier (GCLM) subunit [41]. GCLC is regulated by Nrf2 via NFKB pathway [42]. Hyperoxia demonstrated a significant induction of GCLC mRNA expression in the developing brain. Together with the hyperoxia-induced increase of Nrf2 expression, these results underline the interplay of antioxidant responses [43].

Peroxiredoxin (Prx) and sulfiredoxin (Srx) are important proteins of the thioredoxin family and a key regulator of genes involved in oxidant defense, such as SOD3, Prx1, Srx1, and HO-1, and redox signaling. It is known that non-physiological oxygen concentrations change the balance of the Srx/Prx system in the developing brain [44]. Prx and Srx can act as an antioxidant and Srx solely reduces over-oxidized typical 2-Cys-Prx [45]. Hyperoxic changes elicit reactions of the antioxidant enzyme system, specifically the SODs, which play an essential role in antioxidant defense [37]. Our current data confirm previous studies [44] showing under oxidative stress a significant increase of peroxide reducing protein Prx1 and of antioxidant Srx1 protein expression.

An antioxidant activity of caffeine has been assumed in recent studies in which neuroprotection was demonstrated in patients suffering from neurodegenerative disorders [11,12]. In our study using acute hyperoxia, we demonstrated a highly significant anti-oxidative property of caffeine. A single dose of caffeine resulted in first line in a reduction of the oxidative response of lipid peroxidation, a marker of oxidative stress [46], in generation of hydrogen peroxide $\left(\mathrm{H}_{2} \mathrm{O}_{2}\right)$, and in the relevant context the expression of HO-1 and Nrf2. In the second line, caffeine improved SOD RNA expression 
and suppressed Prx1 and Srx1 protein expressions. These results point to a broad interaction of caffeine with the antioxidant defense network. The reduced SOD expression under hyperoxic conditions could be explained by an exhaustion of the anti-oxidant system which was successfully counteracted by caffeine. Ahotupa et al. showed an initial decrease of SOD in hyperoxic rat brains, followed by a slight induction of its activity at a later time point [47]. Altogether, the findings suggest that the antioxidant defense capacity is diminished during exposure to hyperoxia and, moreover, represents a promising target for protective pharmacological strategies.

\subsection{Inflammatory Response via NFKB Pathway}

Dependent on the level of generated ROS, different redox-sensitive transcription factors are activated. Moderate oxidative stress is related to Nrf2 activation and intermediate amount of ROS initiates an inflammatory response through activation of NFKB pathway [48]. Our results in the developing brain underline a connection between induced Nrf2 expression and increased protein expression of HO-1, Prx1, and Srx1. Moreover, caffeine treatment seems to modify the redox-sensitive response on the Nrf2/Keap1 pathway, since it attenuated the hyperoxia-induced increase of NFKB expression. $\mathrm{NF} \kappa \mathrm{B}$ is activated by different endogenous stimuli, as well as by oxidative stress or cytokines $[49,50]$. In our hyperoxic rat pups, the pro-inflammatory genes $\operatorname{TNF} \alpha, \operatorname{IFN} \gamma, i N O S, \operatorname{IL}-1 \beta$, and IL-18 were induced. An interaction of oxidative stress and inflammatory responses has previously been described [51]. The pro-inflammatory cytokine IL-18 plays an essential role in IFN $\gamma$ induction [52] and is associated with cell death after hyperoxia insult [38]. Excessive NO production causes tissues damage by formation of peroxynitrite. Consequently, nitrotyrosine is being formed and lipid peroxidation gets initiated [53]. Oxidative stress may enhance expression of the inducible isoform of NOS (iNOS) through the activation of $\mathrm{NFKB}$ [54]. Activation of NFKB may also increase the release of pro-inflammatory cytokines which again can induce iNOS, thus resulting in enhanced production of NO. Interestingly, Hoehn et al. [55] demonstrated that hyperoxia induces up-regulation of iNOS in the immature rat brain as a possible cause of cellular damage in the immature brain [56].

In our study, caffeine significantly reduced inflammatory responses. Surprisingly, IL-12 mRNA expression was dramatically reduced under hyperoxia, which was blocked by caffeine. IL-12 is produced by microglia [57], and pro- and anti-inflammatory effects are reported [58,59]. It has to be discussed that caffeine not only exerted beneficial actions in hyperoxic rats but also triggered cellular changes and pro-inflammatory responses in normoxia control rats [60]. Caffeine reduced lipid peroxidation not only in response to hyperoxia but also under normoxic conditions. At the same time, the transcripts of $S O D 2 / 3$ and protein expression of Srx 1 and pro-inflammatory cytokines (IL-1 $\beta$ and IFN $\gamma$ ) increased after caffeine administration at normoxia. Leon-Carmona and Galano disclosed in their functional studies that caffeine may act as radical scavenger [61]. Caffeine also reduced hydrogen levels in lung cells in vitro [62]. In mice, caffeine reduces lipid peroxidation [63]. Cytokine and anti-oxidative enzyme over expression in normoxic exposure could be protective in oxidative stress models $[64,65]$. Chavez-Valdez and co-workers discussed a range of caffeine plasma level appropriate for patient therapy, and higher plasma levels outside of these range coincided with an increase of inflammatory cytokines in a clinical study with preterm infants [18].

\subsection{Apoptosis}

High levels of ROS have been shown to induce apoptosis in the immature brain after hyperoxia [32]. In our study, exposure to high oxygen induced the nuclear acting of PARP-1, an enzyme which is activated by DNA strand breaks, and the caspase-independent AIF, and increased cleavage of caspase-3. In previous studies, exposure to postnatal hyperoxia also caused an increase in apoptotic cell death $[16,44,51,66]$. Anti-apoptotic properties of caffeine, also previously demonstrated by our group [16], were seen in this study by modified levels of PARP-1, AIF, and cleaved caspase-3 levels. In a hypoxic ischemic model of young rats, caffeine also revealed apoptosis-inhibiting effects [67]. Attenuation of PARP-1 inhibiting capacity has also been attributed to caffeine metabolites [68]. In our 
study, elevated PARP-1 and AIF were also found in controls after injection of $10 \mathrm{mg} / \mathrm{kg}$ caffeine. An increase of caspase-3 positive cells was also reported in sham animals of a hypoxia-ischemia study that received $20 \mathrm{mg} / \mathrm{kg}$ caffeine [67]. It seems possible that regulation of neuronal cell survival by caffeine occurs via direct activation of the NFKB pathway [69].

\subsection{Fibrinolytic and Matrix Metalloproteinases System}

Free radicals and ROS seem to activate matrix metalloproteinases (MMPs), with the biological function to degrade extracellular matrix of cerebral blood vessels and neurons [70], and active MMPs may disrupt the vital blood-brain barrier. Hyperoxia led to a drastic increase of MMP2 activation, while tissue inhibitors of MMPs (TIMP)-2, decreased. Caffeine might inhibit the processing of MMP2 through inhibition of TIMP2 expression, but molecular protection might also start further upstream through reduction of $t P a$ transcript expression as found in our study, thus leading to less processing of active MMP. TGF- $\beta$ is a multifunctional cytokine that regulates a broad diversity of physiological and pathological processes. Plasmin releases latent forms of growth factors such as TGF- $\beta$ [71]. TGF- $\beta$ effects on matrix degeneration are characterized by mixed reciprocally action of MMPs and inhibition of TIMPs to reduce the MMP/TIMP balance [72], so caffeine minimizes TGF- $\beta$ expression. Sifringer et al. showed in traumatic and hyperoxic brain injury models a time-dependent increase of MMP activation in correlation to TIMP mRNA expression, and active MMP2 and MMP9 were reduced by protective treatment with erythropoietin [73].

\subsection{Caffeine and Neuroprotection}

For the clinical situation, it is important to precisely define the effects of caffeine on the otherwise healthy brain in order to avoid harm in preterm infants. The increase of apoptotic factors in normoxic newborn pups coincides with higher activity of MMP2 and also with increased NFkB protein expression in these animals. Since the injection of caffeine was performed $15 \mathrm{~min}$ before the beginning of hyperoxia exposure, it is possible that a certain degree of cellular stimulation is caused by caffeine that functions as a protective preconditioning in those animals challenged by hyperoxia later on. Preconditioning has been characterized as a protective procedure in brain injury models involving inflammatory stimulation [74], ischemia [75], and hypoxia [76] prior to the injurious events. Ischemic preconditioning is currently under evaluation for open heart surgery in various clinical centers and studies $[77,78]$. It is possible that caffeine represents a drug that in addition to its anti-oxidant and anti-inflammatory properties might also be useful for protective preconditioning of the brain. For prevention of brain injury in preterm infants, it has been suggested to investigate the use of anti-oxidant compounds such as melatonin, acetylcysteine, or allopurinol [79]. The strategy to use caffeine for brain protection in preterm infants would provide great advantages of a drug being licensed for this vulnerable patient population. The pharmacological properties and safety aspects of caffeine are well known to clinicians taking care of preterm infants, and ethical issues for clinical trials or routine care administration will be minor as compared to most other drug candidates.

\section{Materials and Methods}

\subsection{Animals and Study Design}

All procedures were approved by the state animal welfare authorities (LAGeSo G-0307/09) and followed institutional guidelines. Six-day-old Wistar rats from time-pregnant dams were obtained from Charité-Universitätsmedizin Berlin (Germany) and randomly assigned to cages and treatment. Animals were housed under controlled temperature and light conditions with food and water ad libitum. Experimental procedure and caffeine administration were carried out as described previously [16]. The rat pups were divided into two overarching experimental groups. From Postnatal Day 6 (P6), rat pups and their dams in all experimental groups were exposed to either $80 \%$ oxygen (hyperoxia, OxyCycler BioSpherix, Lacona, NY, USA) or atmospheric air (normoxia). In relation 
to the exposure to oxygen, the pups were divided into further subgroups, depending on the drug administration. Neonatal rats were administered vehicle $(0.9 \%$ saline $)$ or caffeine $(10 \mathrm{mg} / \mathrm{kg})$ as single application. Caffeine (Sigma-Aldrich, Steinheim, Germany) was dissolved in sterile distillated water. Each experimental group consisted of five animals with mixed gender. All injections of drug and vehicle were given intraperitoneally (i.p.) as a fixed proportion of body weight $(100 \mu \mathrm{L} / 10 \mathrm{~g})$. Caffeine or saline were administrated once $15 \mathrm{~min}$ before the start of atmospheric air or oxygen exposure.

\subsection{Tissue Preparation}

After $24 \mathrm{~h}$ (P7) or $48 \mathrm{~h}$ (P8) of exposure, rats were transcardially perfused with normal saline (pH 7.4) under anesthesia (i.p.) of ketamine $(50 \mathrm{mg} / \mathrm{kg})$, xylazine $(10 \mathrm{mg} / \mathrm{kg})$, and acepromazine $(2 \mathrm{mg} / \mathrm{kg})$, then decapitated, the olfactory bulb and cerebellum were removed, and brain hemispheres were snap-frozen in liquid nitrogen and stored at $-80^{\circ} \mathrm{C}$.

\subsection{Protein Extraction}

Protein was extracted as described in [16,44]. Briefly, snap-frozen brain tissue was homogenized in RIPA buffer solution for protein extraction. The homogenate was centrifuged at $3000 \times g\left(4{ }^{\circ} \mathrm{C}\right)$ for $10 \mathrm{~min}$, the microsomal fraction was subsequently centrifuged at $17,000 \times g\left(4^{\circ} \mathrm{C}\right)$ for $20 \mathrm{~min}$, and stored at $-80^{\circ} \mathrm{C}$ until further analysis. After collecting the supernatant, protein concentrations were determined using the Pierce BCA kit (Pierce/Thermo Scientific, Rockford, IL, USA) with 30 min incubation at $37^{\circ} \mathrm{C}$ prior to spectrophotometry at $562 \mathrm{~nm}$.

\subsection{Immunoblotting}

Western blotting was performed as previously described $[16,66]$ for following proteins: apoptosis inducing factor (AIF), cleaved caspase-3 (cleaved Casp3), nuclear factor of kappa light polypeptide gene enhancer in B-cells (NFkB), poly (ADP-ribose) polymerase-1 (PARP-1), peroxiredoxin 1 (Prx1), and sulfiredoxin 1 (Srx1). Briefly, protein extracts (20 $\mathrm{g}$ g per sample) were denatured in Laemmli sample loading buffer at $95^{\circ} \mathrm{C}$, size-fractionated by $12.5 \%$ (for AIF, NFKB, PARP-1, and Prx 1 ) or $15 \%$ (for cleaved casp3 and Srx1) sodium dodecyl sulfate (SDS) polyacrylamide gel electrophoresis and electro transferred in transfer buffer to a nitrocellulose membrane $(0.2 \mu \mathrm{m}$ pore, Bio-Rad, Munich, Germany), or for NFKB to a PVDF membrane ( $0.45 \mu \mathrm{m}$ pore, Merck Millipore, Darmstadt, Germany). Membranes were blocked for $1 \mathrm{~h}$ at room temperature (Srx1 and Prx1 with $1 \%(v / v)$ horse serum in Tris-buffered saline /0.1\% ( $v / v)$ Tween 20 (TBST); AIF, cleaved Casp3, NFkB, and PARP-1 with 5\% $(w / v)$ bovine serum albumin (Serva, Heidelberg, Germany) in TBST). Equal loading and transfer of proteins was confirmed by staining the membranes with Ponceau S solution (Fluka, Buchs, Switzerland). The membranes were incubated overnight at $4{ }^{\circ} \mathrm{C}$ with the following antibodies: rabbit polyclonal anti-AIF (67 kDa; 1:1000; Cell Signaling, Cambridge, UK), rabbit monoclonal anti-cleaved caspase-3 (17 kDa; 1:1000; Cell Signaling), rabbit polyclonal anti-NFkB p65 ( 60 kDa, 1:2500 for cytosolic and 1:750 for nuclear protein fraction; Merck Millipore), rabbit monoclonal anti-PARP-1 (89 kDa; 1:1000; Cell Signaling), goat polyclonal anti-peroxiredoxin 1 (Prx1; 50 kDa dimer; 1:400; Santa Cruz Biotechnology, Heidelberg, Germany), polyclonal goat anti-sulfiredoxin 1 (Srx1; $13 \mathrm{kDa}$; 1:200; Santa Cruz Biotechnology) diluted in $0.5 \%(v / v)$ horse serum or $1 \%(w / v)$ bovine serum albumin in TBST, corresponding to the blocking solution. As reference controls, were used monoclonal mouse anti- $\beta$-actin (42 kDa; 1:10,000; Sigma-Aldrich) and rabbit polyclonal anti- $\alpha$-actinin (100 kDa; 1:1000; Cell Signaling) diluted in $1 \%(w / v)$ bovine serum albumin in TBST. Secondary incubations were performed with horseradish peroxidase-linked polyclonal donkey anti-goat (1:3000; Dianova, Hamburg, Germany), polyclonal rabbit anti-mouse (1:1000; DAKO, Glostrup, Denmark), or polyclonal donkey anti-rabbit (1:4000; Dianova) antibodies, diluted in 1\% $(w / v)$ bovine serum albumin in TBST, respectively. Positive signals were visualized using enhanced chemiluminescence (ECL; Amersham Biosciences, Freiburg, Germany) and quantified using a ChemiDoc ${ }^{\mathrm{TM}} \mathrm{XRS}+$ system and the software Image $\mathrm{Lab}^{\mathrm{TM}}$ (Bio-Rad). Each experiment was repeated three times. 


\subsection{Gelatin Zymography}

Snap-frozen tissue was homogenized in working buffer $(150 \mathrm{mM} \mathrm{NaCl}, 5 \mathrm{mM} \mathrm{CaCl}, 0.05 \%$ $(v / v)$ Brij 35, $1 \%(v / v)$ Triton $\mathrm{X}-100,0.02 \%(w / v) \mathrm{NaN}_{3}, 50 \mathrm{mM}$ Tris-HCl pH 7.4) on ice, followed by centrifugation for $5 \mathrm{~min}$ at $12,000 \times \mathrm{g}$. The protein concentration of the supernatant was measured with the Pierce BCA kit (Pierce/Thermo Scientific). One milligram of protein was used for enzyme enrichment and purification with Gelatin Sepharose ${ }^{\mathrm{TM}}$ 4B (GE Healthcare, Uppsala, Sweden) and eluted in $150 \mu \mathrm{L}$ working buffer containing $10 \%(v / v)$ dimethylsulfoxide. Protein samples mixed with an equal volume of Novex ${ }^{\circledR}$ SDS-sample buffer (Life Technologies GmbH, Darmstadt, Germany), and incubated for $5 \mathrm{~min}$ at room temperature prior to loading to $10 \%$ Novex ${ }^{\circledR}$ gelatin-ready zymogram gel (Life Technologies $\mathrm{GmbH}$ ). Gels were run at $125 \mathrm{~V}$ for $2 \mathrm{~h}$. The gels were incubated in renaturation buffer (Novex ${ }^{\circledR}$, Life Technologies $\mathrm{GmbH}$ ) under gentle agitation for $30 \mathrm{~min}$. They were then equilibrated for $30 \mathrm{~min}$ in developing buffer $\left(\operatorname{Novex}^{\circledR}\right.$, Life Technologies $\mathrm{GmbH}$ ) and incubated in fresh developing buffer at $37^{\circ} \mathrm{C}$ overnight, but at least for $18 \mathrm{~h}$. Gels were washed three times with deionized water under gentle agitation for $5 \mathrm{~min}$ and stained with Coomassie Blue G 250 (SimplyBlue SafeStain, Life Technologies $\mathrm{GmbH}$ ) for $30 \mathrm{~min}$, and washed with deionized water for $30 \mathrm{~min}$. Areas of protease activity appear as clear bands against a dark blue background where the protease has digested the gelatin substrate. Quantification of inverted matrix metalloproteinases (MMP) 2 band density was carried out using a ChemiDoc ${ }^{\mathrm{TM}}$ XRS+ system and the software Quantity One ${ }^{\circledR}$ (Bio-Rad).

\subsection{Thiobarbituric Acid Reactive Substances (TBARS) Assay}

Concentrations of markers of lipid peroxidation thiobarbituric acid reactive substances (TBARS) was determined using the TBARS assay kit (Cayman Chemical, Ann Arbor, MI, USA) according to manufacturer's instructions. Briefly, first a mixture of sample or standard and SDS solution was prepared. A color reagent was added to the mixture and boiled for one hour. The reaction was stopped on ice for $10 \mathrm{~min}$ and centrifuged at $1600 \times \mathrm{g}\left(4^{\circ} \mathrm{C}\right)$ for $10 \mathrm{~min}$. The supernatant was transferred on a 96 well plate and absorbance was read at $530 \mathrm{~nm}$ in a microplate reader. TBARS concentration as a measure for lipid peroxidation was calculated from a malondialdehyde (MDA) standard curve and normalized to the amount of total protein.

\subsection{Heme Oxygenase-1 (HO-1) Assay}

HO-1 concentration was analyzed in samples of brain homogenate using Rat Heme Oxygenase-1 EIA Kit (Precoated, Takara Bio Europe/SAS, Saint-Germain-en-Laye, France) according to manufacturer's instructions. Briefly, $100 \mu \mathrm{L}$ of sample or standard was first loaded and incubated for one hour at room temperature. Then the sample solution was removed and the wells washed three times with $400 \mu \mathrm{L}$ of PBS containing $0.1 \%(v / v)$ Tween 20. Afterwards, $100 \mu \mathrm{L}$ of antibody-POD conjugate solution was added and incubated at room temperature for one hour. The sample solution was removed and ensuing washed four times with $400 \mu \mathrm{L}$ of PBS, aspirating thoroughly between washes. Substrate solution $(100 \mu \mathrm{L})$ was added and incubated for $15 \mathrm{~min}$ at room temperature. The reaction was stopped by addition of $100 \mu \mathrm{L}$ stop solution. The absorbance was read at $450 \mathrm{~nm}$ in a microplate reader. HO-1 concentration was determined by comparing sample to the standard curve and values were expressed as nanograms per milligram of protein.

\subsection{Hydrogen Peroxide Assay}

Hydrogen peroxide $\left(\mathrm{H}_{2} \mathrm{O}_{2}\right)$ was measured in brain homogenates using OxiSelect Hydrogen peroxide assay kit (Cell Biolabs Inc., San Diego, CA, USA) according to manufacturer's instructions. Briefly, $25 \mu \mathrm{L}$ of sample or standard was first added to the microtiter plate wells and then mixed thoroughly with $250 \mu \mathrm{L}$ aqueous working reagent. Afterwards samples were incubated on a shaker for $30 \mathrm{~min}$ at room temperature and the absorbance was read at $540 \mathrm{~nm}$. The peroxide content in unknown samples was determined by comparison with a predetermined $\mathrm{H}_{2} \mathrm{O}_{2}$ standard curve. 


\subsection{Enzyme-Linked Immunosorbent Assays (ELISAs)}

Tumor necrosis factor $\alpha(\mathrm{TNF} \alpha)$, interleukin- $\beta$ (IL-1 $\beta)$, and interferon- $\gamma(\mathrm{IFN}-\gamma)$ concentrations were analyzed in samples of brain homogenate using rat TNF $\alpha /$ TNFSF1A, rat IL-1 $\beta /$ IL-1F2, and rat IFN- $\gamma$ DuoSet ELISA (R\&D Systems GmbH, Wiesbaden-Nordenstadt, Germany) according to manufacturer's instructions. Briefly, 96-well plates were coated with $100 \mu \mathrm{L}$ of capture antibody, incubated overnight, washed with $400 \mu \mathrm{L}$ wash buffer and incubated for $1 \mathrm{~h}$ for blocking with $300 \mu \mathrm{L}$ of reagent diluent. After washing in wash buffer, $100 \mu \mathrm{L}$ of samples or standards, diluted in reagent diluent, were added and incubation preceded for $2 \mathrm{~h}$. Samples were then washed and incubated for $2 \mathrm{~h}$ in the presence of $100 \mu \mathrm{L}$ of biotinylated detection antibody at room temperature. The supernatants were aspirated, the wells washed and $100 \mu \mathrm{L}$ of horseradish peroxidase-conjugated streptavidin was added and incubation continued for $20 \mathrm{~min}$. Samples were washed and $100 \mu \mathrm{L}$ of substrate solution, a 1:1 mixture of $\mathrm{H}_{2} \mathrm{O}_{2}$ and tetramethylbenzidine ( $\mathrm{R} \& \mathrm{D}$ Systems $\mathrm{GmbH}$ ), was added. Samples were incubated in the dark for $20 \mathrm{~min}$ and the reaction was stopped using $50 \mu \mathrm{L} 2 \mathrm{~N} \mathrm{H}_{2} \mathrm{SO}_{4}$. Plates were read at $450 \mathrm{~nm}$ and $\mathrm{TNF} \alpha, \mathrm{IL}-1 \beta$, and IFN- $\gamma$ concentrations were estimated from the standard curve and expressed as picograms per milligram protein.

\subsection{RNA Extraction and Real-Time PCR}

Gene expression analysis was performed as previously described [16,66]. Total RNA was isolated from snap-frozen tissue by acidic phenol/chloroform extraction (peqGOLD RNAPure ${ }^{\mathrm{TM}}$; PEQLAB Biotechnologie, Erlangen, Germany) and $2 \mu \mathrm{g}$ of RNA was reverse transcribed. The PCR products of caspase-3 (Casp3), glutamate-cysteine ligase catalytic subunit (GCLC), interferon- $\gamma($ IFN- $\gamma$ ), interleukin-1 $\beta(I L-1 \beta)$, interleukin-12b (IL-12b), interleukin-18 (IL-18), inducible nitric oxide synthase (iNOS), Kelch-like ECH-associated protein 1 (Keap1), nuclear factor of kappa light polypeptide gene

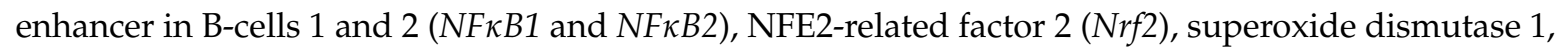
2 and 3 (SOD1, SOD2, and SOD3), tissue inhibitor of metalloproteinase 1 and 2 (TIMP1 and TIMP2), tumor necrosis factor $\alpha(T N F \alpha)$, tissue plasminogen activator $(t P a)$, and hypoxanthine-guanine phosphoribosyltransferase (HPRT) were quantified in real time, using dye-labeled fluorogenic reporter oligonucleotide probes and primers (Table 1).

Table 1. Sequences of oligonucleotides.

\begin{tabular}{|c|c|c|}
\hline cDNA & Oligonucleotide Sequence $5^{\prime}-3^{\prime}$ & Accession No. \\
\hline $\begin{array}{l}\text { forward } \\
\text { reverse } \\
\text { probe }\end{array}$ & $\begin{array}{c}\text { HPRT } \\
\text { GGAAAGAACGTCTTGATTGTTGAA } \\
\text { CCAACACTTCGAGAGGTCCTTTT } \\
\text { CTTTCCTTGGTCAAGCAGTACAGCCCC }\end{array}$ & NM_012583.2 \\
\hline $\begin{array}{l}\text { forward } \\
\text { reverse } \\
\text { probe }\end{array}$ & $\begin{array}{c}c \boldsymbol{c a s p 3} \\
\text { ACAGTGGAACTGACGATGATATGG } \\
\text { AATAGTAACCGGGTGCGGTAGA } \\
\text { ATGCCAGAAGATACCAGTGG }\end{array}$ & NM_012922.2 \\
\hline $\begin{array}{l}\text { forward } \\
\text { reverse } \\
\text { probe }\end{array}$ & $\begin{array}{c}\text { GCLC } \\
\text { GGAGGACAACATGAGGAAACG } \\
\text { GCTCTGGCAGTGTGAATCCA } \\
\text { GAGGCTACTTCTGTATTAGG }\end{array}$ & NM_012815.2 \\
\hline $\begin{array}{l}\text { forward } \\
\text { reverse } \\
\text { probe }\end{array}$ & $\begin{array}{c}\text { IFN- } \gamma \\
\text { GCAAAAGGACGGTAACACGAA } \\
\text { ATGGCCTGGTTGTCTTTCAAGA } \\
\text { TCTCTTTCTACCTCAGACTC }\end{array}$ & NM_138880.2 \\
\hline
\end{tabular}


Table 1. Cont.

\begin{tabular}{|c|c|c|}
\hline cDNA & Oligonucleotide Sequence $5^{\prime}-3^{\prime}$ & Accession No. \\
\hline $\begin{array}{l}\text { forward } \\
\text { reverse } \\
\text { probe }\end{array}$ & $\begin{array}{c}\boldsymbol{I L} \mathbf{L} \mathbf{- 1} \boldsymbol{\beta} \\
\text { CTCCACCTCAATGGACAGAACA } \\
\text { CACAGGGATTTTGTCGTTGCT } \\
\text { CTCCATGAGCTTTGTACAAG }\end{array}$ & NM_031512.2 \\
\hline $\begin{array}{l}\text { forward } \\
\text { reverse } \\
\text { probe }\end{array}$ & $\begin{array}{c}\qquad \boldsymbol{I L - 1 2 b} \\
\text { TGCTGCTCCACAAGAAGGAA } \\
\text { TTGGTGCTTCACACTTCAGGAA } \\
\text { ATGGAATTTGGTCCACCGAG }\end{array}$ & NM_022611.1 \\
\hline $\begin{array}{l}\text { forward } \\
\text { reverse } \\
\text { probe }\end{array}$ & $\begin{array}{c}\qquad \mathbf{I L - 1 8} \\
\text { CGGAGCATAAATGACCAAGTTCTC } \\
\text { TGGGATTCGTTGGCTGTTC } \\
\text { TTGACAAAAGAAACCCGCCTG }\end{array}$ & NM_019165.1 \\
\hline $\begin{array}{l}\text { forward } \\
\text { reverse } \\
\text { probe }\end{array}$ & $\begin{array}{c}i N O S \\
\text { AGCTGTAGCACTGCATCAGAAATG } \\
\text { CAGTAATGGCCGACCTGATGT } \\
\text { CAGACACATACTTTACGCCAC }\end{array}$ & NM_012611.3 \\
\hline $\begin{array}{l}\text { forward } \\
\text { reverse } \\
\text { probe }\end{array}$ & $\begin{array}{c}\text { Keap1 } \\
\text { GATCGGCTGCACGGAACT } \\
\text { GCAGTGTGACAGGTTGAAGAACTC } \\
\text { CTCGGGAGTATATCTACATGC }\end{array}$ & NM_057152.2 \\
\hline $\begin{array}{l}\text { forward } \\
\text { reverse } \\
\text { probe }\end{array}$ & $\begin{array}{c}\boldsymbol{N} \boldsymbol{N \boldsymbol { \kappa } \boldsymbol { B } \mathbf { 1 }} \\
\text { GACCCAAGGACATGGTGGTT } \\
\text { TCATCCGTGCTTCCAGTGTTT } \\
\text { CTGGGAATACTTCACGTGAC }\end{array}$ & NM_001276711.1 \\
\hline $\begin{array}{l}\text { forward } \\
\text { reverse } \\
\text { probe }\end{array}$ & $\begin{array}{c}\boldsymbol{N} \boldsymbol{N} \boldsymbol{\kappa} \boldsymbol{B} \mathbf{2} \\
\text { GCCTAAACAGCGAGGCTTCA } \\
\text { TCTTCCGGCCCTTCTCACT } \\
\text { TTTCGATATGGCTGTGAAGG }\end{array}$ & NM_001008349.1 \\
\hline $\begin{array}{l}\text { forward } \\
\text { reverse } \\
\text { probe }\end{array}$ & $\begin{array}{c}N r f 2 \\
\text { ACTCCCAGGTTGCCCACAT } \\
\text { GCGACTCATGGTCATCTACAAATG } \\
\text { CTTTGAAGACTGTATGCAGC }\end{array}$ & NM_031789.2 \\
\hline $\begin{array}{l}\text { forward } \\
\text { reverse } \\
\text { probe }\end{array}$ & $\begin{array}{c}\text { SOD1 } \\
\text { CAGAAGGCAAGCGGTGAAC } \\
\text { CCCCATATTGATGGACATGGA } \\
\text { TACAGGATTAACTGAAGGCG }\end{array}$ & NM_017050.1 \\
\hline $\begin{array}{l}\text { forward } \\
\text { reverse } \\
\text { probe }\end{array}$ & $\begin{array}{c}\text { SOD2 } \\
\text { GACCTACGTGAACAATCTGAACGT } \\
\text { AGGCTGAAGAGCAACCTGAGTT } \\
\text { ACCGAGGAGAAGTACCACGA }\end{array}$ & NM_017051.2 \\
\hline $\begin{array}{l}\text { forward } \\
\text { reverse } \\
\text { probe }\end{array}$ & $\begin{array}{c}\text { SOD3 } \\
\text { GGAGAGTCCGGTGTCGACTTAG } \\
\text { CTCCATCCAGATCTCCAGGTCTT } \\
\text { CTGGTTGAGAAGATAGGCGA }\end{array}$ & NM_012880.1 \\
\hline $\begin{array}{l}\text { forward } \\
\text { reverse } \\
\text { probe }\end{array}$ & $\begin{array}{c}\text { TGF } \boldsymbol{F} \boldsymbol{\beta} \\
\text { CCTGCAGAGATTCAAGTCAACTGT } \\
\text { GTCAGCAGCCGGTTACCAA } \\
\text { CAACAATTCCTGGCGTT }\end{array}$ & NM_021578.2 \\
\hline $\begin{array}{l}\text { forward } \\
\text { reverse } \\
\text { probe }\end{array}$ & $\begin{array}{c}\text { TIMP1 } \\
\text { CGGACCTGGTTATAAGGGCTAA } \\
\text { CGTCGAATCCTTTGAGCATCT } \\
\text { AGAAATCATCGAGACCACCT }\end{array}$ & NM_053819.1 \\
\hline
\end{tabular}


Table 1. Cont.

\begin{tabular}{ccc}
\hline cDNA & Oligonucleotide Sequence $\mathbf{5}^{\prime} \mathbf{- 3}^{\prime}$ & Accession No. \\
\hline $\begin{array}{c}\text { TIMP2 } \\
\text { forward } \\
\text { probe }\end{array}$ & $\begin{array}{c}\text { GGCAACCCCATCAAGAGGAT } \\
\text { GGGCCGTGTAGATAAATTCGAT }\end{array}$ & NM_021989.2 \\
& AGATGTTCAAAGGACCTGAC & \\
forward & TCAGAAGAGGAGCTCGGTCCTA & NM_013151.2 \\
$\begin{array}{c}\text { reverse } \\
\text { probe }\end{array}$ & TGGGACGTAGCCATGACTGAT & \\
CAGAGATGAACAGACTCAGA & \\
$\begin{array}{c}\text { forward } \\
\text { reverse } \\
\text { probe }\end{array}$ & CCCCCAATCTGTGTCCTTCTAAC & NM_012675.2 \\
\hline
\end{tabular}

The FAM spectral data were collected from reactions carried out in separate tubes using the same stock of cDNA to avoid spectral overlap between FAM/TAMRA and limitations of reagents. PCR and detection were performed in triplicate and repeated two times for each sample in $11 \mu \mathrm{L}$ reaction mix, which contained $5 \mu \mathrm{L}$ of $2 \times$ KAPA PROBE FAST qPCR Master mix (PEQLAB Biotechnologie), $2.5 \mu \mathrm{L}$ of $1.25 \mu \mathrm{M}$ oligonucleotide mix, $0.5 \mu \mathrm{L}(0.5 \mu \mathrm{M})$ of probe (BioTeZ, Berlin, Germany), and 3 to $17 \mathrm{ng}$ of cDNA template with HPRT used as an internal reference. The PCR amplification was performed in 96-well optical reaction plates for 40 cycles with each cycle at $94{ }^{\circ} \mathrm{C}$ for $15 \mathrm{~s}$ and $60{ }^{\circ} \mathrm{C}$ for $1 \mathrm{~min}$. The expression of target genes was analyzed with the StepOnePlus real-time PCR system (Life Technologies) according to the $2^{-\Delta \Delta C t}$ method [80].

\subsection{Statistical Analyses}

All data are expressed as the mean \pm standard error of the mean (SEM). Differences between the control group and experimental groups (oxygen exposure and/or caffeine application) were analyzed using a two-way analysis of variance (ANOVA) with the factors hyperoxia exposure, caffeine, and their interaction. To determine differences between individual groups, each two-way ANOVA was followed by a Bonferroni post-hoc test. A two-sided $p$-value of $<0.05$ was considered significant. Results of the analyses were represented normalized as $100 \%$ value of control ( $24 \mathrm{~h}$ and $48 \mathrm{~h}$, respectively). For the real-time PCR data, the $100 \%$ value of control represented the $C_{\mathrm{T}}$ values, while $C_{\mathrm{T}}$ was defined as the threshold cycle number of PCRs at which amplified product was first detected. For protein data (immunoblotting, ELISA, gelatin zymography), the $100 \%$ value of control represented the protein concentration or molarity (ELISA), intensity ratio of pixel size (immunoblotting), or inverted intensity of pixel size (gelatin zymography). All graphics and statistical analyses were performed using the GraphPad Prism 6.0 software for Windows (GraphPad Software, La Jolla, CA, USA).

\section{Conclusions}

In summary, our study reveals that single administration of caffeine in oxygen-induced brain injury leads to improved neuroprotective response. Exposure to high oxygen in the developmental brain of six-day-old rat pups resulted in increased levels of lipid peroxidation, enhanced generation of hydrogen peroxidase and heme oxygenase-1, decreased anti-oxidative response, up-regulated pro-inflammatory cytokines expression, changed balanced redox-sensitive reply, and promoted extracellular matrix degeneration and apoptotic cascade. All these consequences of hyperoxia can be reversed by caffeine treatment.

Our study suggests that caffeine is a drug that exerts neuroprotective effects on the developing brain due to its anti-oxidant, anti-inflammatory, and anti-apoptotic properties. Future research should 
focus on the investigation of caffeine for preconditioning and further enhance the knowledge about safety of caffeine use in the immature brain.

Acknowledgments: We thank Giang Tong (German Heart Institute, Berlin, Germany) for proofreading the manuscript. Ulrike Weichelt is a fellow of the Promotionsstipendium Charité-Universitätsmedizin, Berlin, Germany and of the Hypatia Program, University of Applied Sciences, Berlin, Germany. This work was supported by Förderverein für frühgeborene Kinder an der Charité e.V., Berlin, Germany.

Author Contributions: Stefanie Endesfelder conceived and supervised the whole project, performed all animal experiments, co-performed most of the experiments, interpreted the results and performed statistical analysis, and wrote and prepared the manuscript. Ulrike Weichelt performed and analyzed immunoblotting and quantitative reverse transcription PCR experiments. Evelyn Strauß performed and analyzed ELISA experiments. Anja Schlör performed and analyzed immunoblotting experiments for Prx1 and Srx1. Marco Sifringer and Till Scheuer performed animal experiments, provided technical help, and contributed to the critical discussion of the manuscript. Christoph Bührer interpreted the results and revised the manuscript. Thomas Schmitz interpreted the results and prepared the manuscript.

Conflicts of Interest: The authors declare no conflict of interest.

\section{References}

1. Marlow, N.; Wolke, D.; Bracewell, M.A.; Samara, M.; Group, E.S. Neurologic and developmental disability at six years of age after extremely preterm birth. N. Engl. J. Med. 2005, 352, 9-19. [CrossRef] [PubMed]

2. Wilson-Costello, D.; Friedman, H.; Minich, N.; Fanaroff, A.A.; Hack, M. Improved survival rates with increased neurodevelopmental disability for extremely low birth weight infants in the 1990s. Pediatrics 2005, 115, 997-1003. [CrossRef] [PubMed]

3. Volpe, J.J. Perinatal brain injury: From pathogenesis to neuroprotection. Ment. Retard. Dev. Disabil. Res. Rev. 2001, 7, 56-64. [CrossRef]

4. Perrone, S.; Tataranno, M.L.; Stazzoni, G.; Buonocore, G. Biomarkers of oxidative stress in fetal and neonatal diseases. J. Mater. Fetal Neonatal Med. 2012, 25, 2575-2578. [CrossRef] [PubMed]

5. Saugstad, O.D. Update on oxygen radical disease in neonatology. Curr. Opin. Obstet. Gynecol. 2001, 13, 147-153. [CrossRef] [PubMed]

6. Stone, W.L.; Shah, D.; Hollinger, S.M. Retinopathy of prematurity: An oxidative stress neonatal disease. Front. Biosci. 2016, 21, 165-177. [CrossRef]

7. Buonocore, G.; Perrone, S.; Longini, M.; Vezzosi, P.; Marzocchi, B.; Paffetti, P.; Bracci, R. Oxidative stress in preterm neonates at birth and on the seventh day of life. Pediatr. Res. 2002, 52, 46-49. [CrossRef] [PubMed]

8. Vento, M.; Escobar, J.; Cernada, M.; Escrig, R.; Aguar, M. The use and misuse of oxygen during the neonatal period. Clin. Perinatol. 2012, 39, 165-176. [CrossRef] [PubMed]

9. O'Donovan, D.J.; Fernandes, C.J. Free radicals and diseases in premature infants. Antioxid. Redox Signal. 2004, 6, 169-176. [CrossRef] [PubMed]

10. Lee, Y.S.; Chou, Y.H. Antioxidant profiles in full term and preterm neonates. Chang Gung Med. J. 2005, 28, 846-851. [PubMed]

11. Prasanthi, J.R.; Dasari, B.; Marwarha, G.; Larson, T.; Chen, X.; Geiger, J.D.; Ghribi, O. Caffeine protects against oxidative stress and Alzheimer's disease-like pathology in rabbit hippocampus induced by cholesterol-enriched diet. Free Radic. Biol. Med. 2010, 49, 1212-1220. [CrossRef] [PubMed]

12. Ullah, F.; Ali, T.; Ullah, N.; Kim, M.O. Caffeine prevents d-galactose-induced cognitive deficits, oxidative stress, neuroinflammation and neurodegeneration in the adult rat brain. Neurochem. Int. 2015, 90, 114-124. [CrossRef] [PubMed]

13. Henderson-Smart, D.J.; de Paoli, A.G. Methylxanthine treatment for apnoea in preterm infants. Cochrane Database Syst. Rev. 2010, CD000140. [CrossRef]

14. Schmidt, B.; Roberts, R.S.; Davis, P.; Doyle, L.W.; Barrington, K.J.; Ohlsson, A.; Solimano, A.; Tin, W. Caffeine therapy for apnea of prematurity. N. Engl. J. Med. 2006, 354, 2112-2121. [CrossRef] [PubMed]

15. Schmidt, B.; Roberts, R.S.; Davis, P.; Doyle, L.W.; Barrington, K.J.; Ohlsson, A.; Solimano, A.; Tin, W. Long-term effects of caffeine therapy for apnea of prematurity. N. Engl. J. Med. 2007, 357, 1893-1902. [CrossRef] [PubMed]

16. Endesfelder, S.; Zaak, I.; Weichelt, U.; Bührer, C.; Schmitz, T. Caffeine protects neuronal cells against injury caused by hyperoxia in the immature brain. Free Radic. Biol. Med. 2014, 67, 221-234. [CrossRef] 
17. Rivkees, S.A.; Wendler, C.C. Adverse and protective influences of adenosine on the newborn and embryo: Implications for preterm white matter injury and embryo protection. Pediatr. Res. 2011, 69, 271-278. [CrossRef] [PubMed]

18. Chavez Valdez, R.; Ahlawat, R.; Wills-Karp, M.; Nathan, A.; Ezell, T.; Gauda, E.B. Correlation between serum caffeine levels and changes in cytokine profile in a cohort of preterm infants. J. Pediatr. 2011, 158, 57-64. [CrossRef] [PubMed]

19. Weichelt, U.; Cay, R.; Schmitz, T.; Strauss, E.; Sifringer, M.; Buhrer, C.; Endesfelder, S. Prevention of hyperoxia-mediated pulmonary inflammation in neonatal rats by caffeine. Eur. Respir. J. 2013, 41, 966-973. [CrossRef] [PubMed]

20. Taha, D.; Kirkby, S.; Nawab, U.; Dysart, K.C.; Genen, L.; Greenspan, J.S.; Aghai, Z.H. Early caffeine therapy for prevention of bronchopulmonary dysplasia in preterm infants. J. Mater. Fetal Neonatal Med. 2014, 27, 1698-1702. [CrossRef] [PubMed]

21. Patel, R.M.; Leong, T.; Carlton, D.P.; Vyas-Read, S. Early caffeine therapy and clinical outcomes in extremely preterm infants. J. Perinatol. 2013, 33, 134-140. [CrossRef] [PubMed]

22. Bauer, J.; Maier, K.; Linderkamp, O.; Hentschel, R. Effect of caffeine on oxygen consumption and metabolic rate in very low birth weight infants with idiopathic apnea. Pediatrics 2001, 107, 660-663. [CrossRef] [PubMed]

23. Steer, P.; Flenady, V.; Shearman, A.; Charles, B.; Gray, P.H.; Henderson-Smart, D.; Bury, G.; Fraser, S.; Hegarty, J.; Rogers, Y.; et al. High dose caffeine citrate for extubation of preterm infants: A randomised controlled trial. Arch. Dis. Child. Fetal Neonatal Ed. 2004, 89, F499-F503. [CrossRef] [PubMed]

24. Henderson-Smart, D.J.; Steer, P.A. Caffeine versus theophylline for apnea in preterm infants. Cochrane Database Syst. Rev. 2010, CD000273. [CrossRef]

25. Shi, X.; Dalal, N.S.; Jain, A.C. Antioxidant behaviour of caffeine: Efficient scavenging of hydroxyl radicals. Food Chem. Toxicol. 1991, 29, 1-6. [CrossRef]

26. Devasagayam, T.P.; Kamat, J.P.; Mohan, H.; Kesavan, P.C. Caffeine as an antioxidant: Inhibition of lipid peroxidation induced by reactive oxygen species. Biochim. Biophys. Acta 1996, 1282, 63-70. [CrossRef]

27. Barcelos, R.P.; Souza, M.A.; Amaral, G.P.; Stefanello, S.T.; Bresciani, G.; Fighera, M.R.; Soares, F.A.; Barbosa, N.V. Caffeine supplementation modulates oxidative stress markers in the liver of trained rats. Life Sci. 2014, 96, 40-45. [CrossRef] [PubMed]

28. Tunc, T.; Aydemir, G.; Karaoglu, A.; Cekmez, F.; Kul, M.; Aydinoz, S.; Babacan, O.; Yaman, H.; Sarici, S.U. Toll-like receptor levels and caffeine responsiveness in rat pups during perinatal period. Regul. Pept. 2013, 182, 41-44. [CrossRef] [PubMed]

29. Chavez-Valdez, R.; Wills-Karp, M.; Ahlawat, R.; Cristofalo, E.A.; Nathan, A.; Gauda, E.B. Caffeine modulates TNF- $\alpha$ production by cord blood monocytes: The role of adenosine receptors. Pediatr. Res. 2009, 65, $203-208$. [CrossRef] [PubMed]

30. Li, J.; Li, G.; Hu, J.L.; Fu, X.H.; Zeng, Y.J.; Zhou, Y.G.; Xiong, G.; Yang, N.; Dai, S.S.; He, F.T. Chronic or high dose acute caffeine treatment protects mice against oleic acid-induced acute lung injury via an adenosine A2A receptor-independent mechanism. Eur. J. Pharmacol. 2011, 654, 295-303. [CrossRef] [PubMed]

31. Tsutsui, S.; Schnermann, J.; Noorbakhsh, F.; Henry, S.; Yong, V.W.; Winston, B.W.; Warren, K.; Power, C. A1 adenosine receptor upregulation and activation attenuates neuroinflammation and demyelination in a model of multiple sclerosis. J. Neurosci. 2004, 24, 1521-1529. [CrossRef] [PubMed]

32. Ikonomidou, C.; Kaindl, A.M. Neuronal death and oxidative stress in the developing brain. Antioxid. Redox Signal. 2011, 14, 1535-1550. [CrossRef] [PubMed]

33. Chua, C.O.; Vinukonda, G.; Hu, F.; Labinskyy, N.; Zia, M.T.; Pinto, J.; Csiszar, A.; Ungvari, Z.; Ballabh, P. Effect of hyperoxic resuscitation on propensity of germinal matrix haemorrhage and cerebral injury. Neuropathol. Appl. Neurobiol. 2010, 36, 448-458. [CrossRef] [PubMed]

34. Waldbaum, S.; Patel, M. Mitochondrial dysfunction and oxidative stress: A contributing link to acquired epilepsy? J. Bioenerg. Biomembr. 2010, 42, 449-455. [CrossRef] [PubMed]

35. Gozzelino, R.; Jeney, V.; Soares, M.P. Mechanisms of cell protection by heme oxygenase-1. Annu. Rev. Pharmacol. Toxicol. 2010, 50, 323-354. [CrossRef] [PubMed]

36. Ho, E.; Karimi Galougahi, K.; Liu, C.C.; Bhindi, R.; Figtree, G.A. Biological markers of oxidative stress: Applications to cardiovascular research and practice. Redox Biol. 2013, 1, 483-491. [CrossRef] [PubMed] 
37. Zaghloul, N.; Nasim, M.; Patel, H.; Codipilly, C.; Marambaud, P.; Dewey, S.; Schiffer, W.K.; Ahmed, M. Overexpression of extracellular superoxide dismutase has a protective role against hyperoxia-induced brain injury in neonatal mice. FEBS J. 2012, 279, 871-881. [CrossRef] [PubMed]

38. Sifringer, M.; Brait, D.; Weichelt, U.; Zimmerman, G.; Endesfelder, S.; Brehmer, F.; von Haefen, C.; Friedman, A.; Soreq, H.; Bendix, I.; et al. Erythropoietin attenuates hyperoxia-induced oxidative stress in the developing rat brain. Brain Behav. Immun. 2010, 24, 792-799. [CrossRef] [PubMed]

39. Morse, D.; Choi, A.M. Heme oxygenase-1: From bench to bedside. Am. J. Respir. Crit. Care Med. 2005, 172, 660-670. [CrossRef] [PubMed]

40. Bryan, H.K.; Olayanju, A.; Goldring, C.E.; Park, B.K. The Nrf2 cell defence pathway: Keap1-dependent and -independent mechanisms of regulation. Biochem. Pharmacol. 2013, 85, 705-717. [CrossRef] [PubMed]

41. Wu, G.; Fang, Y.Z.; Yang, S.; Lupton, J.R.; Turner, N.D. Glutathione metabolism and its implications for health. J. Nutr. 2004, 134, 489-492. [PubMed]

42. Yang, H.; Magilnick, N.; Lee, C.; Kalmaz, D.; Ou, X.; Chan, J.Y.; Lu, S.C. Nrf1 and Nrf2 regulate rat glutamate-cysteine ligase catalytic subunit transcription indirectly via NF-kB and AP-1. Mol. Cell. Biol. 2005, 25, 5933-5946. [CrossRef] [PubMed]

43. Ma, Q. Role of nrf2 in oxidative stress and toxicity. Annu. Rev. Pharmacol. Toxicol. 2013, 53, 401-426. [CrossRef] [PubMed]

44. Bendix, I.; Weichelt, U.; Strasser, K.; Serdar, M.; Endesfelder, S.; von Haefen, C.; Heumann, R.; Ehrkamp, A.; Felderhoff-Mueser, U.; Sifringer, M. Hyperoxia changes the balance of the thioredoxin/peroxiredoxin system in the neonatal rat brain. Brain Res. 2012, 1484, 68-75. [CrossRef] [PubMed]

45. Sandberg, M.; Patil, J.; D'Angelo, B.; Weber, S.G.; Mallard, C. NRF2-regulation in brain health and disease: Implication of cerebral inflammation. Neuropharmacology 2014, 79, 298-306. [CrossRef] [PubMed]

46. Esterbauer, H.; Cheeseman, K.H. Determination of aldehydic lipid peroxidation products: Malonaldehyde and 4-hydroxynonenal. Methods Enzymol. 1990, 186, 407-421. [PubMed]

47. Ahotupa, M.; Mantyla, E.; Peltola, V.; Puntala, A.; Toivonen, H. Pro-oxidant effects of normobaric hyperoxia in rat tissues. Acta Physiol. Scand. 1992, 145, 151-157. [CrossRef] [PubMed]

48. Halliwell, B.; Gutteridge, J.M.C. Free Radicals in Biology and Medicine, 5th ed.; Oxford University Press: Oxford, UK, 2015.

49. Trachootham, D.; Lu, W.; Ogasawara, M.A.; Nilsa, R.D.; Huang, P. Redox regulation of cell survival. Antioxid. Redox Signal. 2008, 10, 1343-1374. [CrossRef] [PubMed]

50. Yadav, S.; Gupta, S.P.; Srivastava, G.; Srivastava, P.K.; Singh, M.P. Role of secondary mediators in caffeine-mediated neuroprotection in maneb- and paraquat-induced Parkinson's disease phenotype in the mouse. Neurochem. Res. 2012, 37, 875-884. [CrossRef] [PubMed]

51. Sifringer, M.; von Haefen, C.; Krain, M.; Paeschke, N.; Bendix, I.; Buhrer, C.; Spies, C.D.; Endesfelder, S. Neuroprotective effect of dexmedetomidine on hyperoxia-induced toxicity in the neonatal rat brain. Oxidative Med. Cell. Longev. 2015, 2015, 530371. [CrossRef] [PubMed]

52. Yamada, M.; Kubo, H.; Kobayashi, S.; Ishizawa, K.; Sasaki, H. Interferon-gamma: A key contributor to hyperoxia-induced lung injury in mice. Am. J. Physiol. Lung Cell Mol. Physiol. 2004, 287, L1042-L1047. [CrossRef] [PubMed]

53. Beckman, J.S.; Koppenol, W.H. Nitric oxide, superoxide, and peroxynitrite: The good, the bad, and ugly. Am. J. Physiol. 1996, 271, C1424-C1437. [PubMed]

54. Griscavage, J.M.; Wilk, S.; Ignarro, L.J. Inhibitors of the proteasome pathway interfere with induction of nitric oxide synthase in macrophages by blocking activation of transcription factor NF-кB. Proc. Natl. Acad. Sci. USA 1996, 93, 3308-3312. [CrossRef] [PubMed]

55. Hoehn, T.; Felderhoff-Mueser, U.; Maschewski, K.; Stadelmann, C.; Sifringer, M.; Bittigau, P.; Koehne, P.; Hoppenz, M.; Obladen, M.; Buhrer, C. Hyperoxia causes inducible nitric oxide synthase-mediated cellular damage to the immature rat brain. Pediatr. Res. 2003, 54, 179-184. [CrossRef] [PubMed]

56. Ikeno, S.; Nagata, N.; Yoshida, S.; Takahashi, H.; Kigawa, J.; Terakawa, N. Immature brain injury via peroxynitrite production induced by inducible nitric oxide synthase after hypoxia-ischemia in rats. J. Obstet. Gynaecol. Res. 2000, 26, 227-234. [CrossRef] [PubMed]

57. Taoufik, Y.; de Goer de Herve, M.G.; Giron-Michel, J.; Durali, D.; Cazes, E.; Tardieu, M.; Azzarone, B.; Delfraissy, J.F. Human microglial cells express a functional IL-12 receptor and produce IL-12 following IL-12 stimulation. Eur. J. Immunol. 2001, 31, 3228-3239. [CrossRef] 
58. Chang, H.D.; Radbruch, A. The pro- and anti-inflammatory potential of interleukin-12. Ann. N. Y. Acad. Sci. 2007, 1109, 40-46. [CrossRef] [PubMed]

59. Murphy, C.A.; Langrish, C.L.; Chen, Y.; Blumenschein, W.; McClanahan, T.; Kastelein, R.A.; Sedgwick, J.D.; Cua, D.J. Divergent pro- and anti-inflammatory roles for IL-23 and IL-12 in joint autoimmune inflammation. J. Exp. Med. 2003, 198, 1951-1957. [CrossRef] [PubMed]

60. Zeidan-Chulia, F.; Gelain, D.P.; Kolling, E.A.; Rybarczyk-Filho, J.L.; Ambrosi, P.; Terra, S.R.; Pires, A.S.; da Rocha, J.B.; Behr, G.A.; Moreira, J.C. Major components of energy drinks (caffeine, taurine, and guarana) exert cytotoxic effects on human neuronal SH-SY5Y cells by decreasing reactive oxygen species production. Oxidative Med. Cell. Longev. 2013, 2013, 791795. [CrossRef] [PubMed]

61. Leon-Carmona, J.R.; Galano, A. Is caffeine a good scavenger of oxygenated free radicals? J. Phys. Chem. B 2011, 115, 4538-4546. [CrossRef] [PubMed]

62. Tiwari, K.K.; Chu, C.; Couroucli, X.; Moorthy, B.; Lingappan, K. Differential concentration-specific effects of caffeine on cell viability, oxidative stress, and cell cycle in pulmonary oxygen toxicity in vitro. Biochem. Biophys. Res. Commun. 2014, 450, 1345-1350. [CrossRef] [PubMed]

63. Pohanka, M. Caffeine alters oxidative homeostasis in the body of BALB/c mice. Bratislavske Lekarske Listy 2014, 115, 699-703. [CrossRef] [PubMed]

64. Motterlini, R.; Foresti, R.; Bassi, R.; Green, C.J. Curcumin, an antioxidant and anti-inflammatory agent, induces heme oxygenase- 1 and protects endothelial cells against oxidative stress. Free Radic. Biol. Med. 2000, 28, 1303-1312. [CrossRef]

65. Ran, Q.; Liang, H.; Gu, M.; Qi, W.; Walter, C.A.; Roberts, L.J., 2nd; Herman, B.; Richardson, A.; van Remmen, $\mathrm{H}$. Transgenic mice overexpressing glutathione peroxidase 4 are protected against oxidative stress-induced apoptosis. J. Biol. Chem. 2004, 279, 55137-55146. [CrossRef] [PubMed]

66. Schmitz, T.; Krabbe, G.; Weikert, G.; Scheuer, T.; Matheus, F.; Wang, Y.; Mueller, S.; Kettenmann, H.; Matyash, V.; Buhrer, C.; et al. Minocycline protects the immature white matter against hyperoxia. Exp. Neurol. 2014, 254, 153-165. [CrossRef] [PubMed]

67. Kilicdag, H.; Daglioglu, Y.K.; Erdogan, S.; Zorludemir, S. Effects of caffeine on neuronal apoptosis in neonatal hypoxic-ischemic brain injury. J. Mater. Fetal Neonatal Med. 2014, 27, 1470-1475. [CrossRef] [PubMed]

68. Geraets, L.; Moonen, H.J.; Wouters, E.F.; Bast, A.; Hageman, G.J. Caffeine metabolites are inhibitors of the nuclear enzyme poly(ADP-ribose)polymerase-1 at physiological concentrations. Biochem. Pharmacol. 2006, 72, 902-910. [CrossRef] [PubMed]

69. Barkett, M.; Gilmore, T.D. Control of apoptosis by Rel/NF-kB transcription factors. Oncogene 1999, 18, 6910-6924. [CrossRef] [PubMed]

70. Gu, Y.; Dee, C.M.; Shen, J. Interaction of free radicals, matrix metalloproteinases and caveolin-1 impacts blood-brain barrier permeability. Front. Biosci. 2011, 3, 1216-1231. [CrossRef]

71. Coutts, A.; Chen, G.; Stephens, N.; Hirst, S.; Douglas, D.; Eichholtz, T.; Khalil, N. Release of biologically active TGF- $\beta$ from airway smooth muscle cells induces autocrine synthesis of collagen. Am. J. Physiol. Lung Cell Mol. Physiol. 2001, 280, L999-L1008. [PubMed]

72. Millis, A.J.; Hoyle, M.; McCue, H.M.; Martini, H. Differential expression of metalloproteinase and tissue inhibitor of metalloproteinase genes in aged human fibroblasts. Exp. Cell Res. 1992, 201, 373-379. [CrossRef]

73. Sifringer, M.; Genz, K.; Brait, D.; Brehmer, F.; Lober, R.; Weichelt, U.; Kaindl, A.M.; Gerstner, B.; Felderhoff-Mueser, U. Erythropoietin attenuates hyperoxia-induced cell death by modulation of inflammatory mediators and matrix metalloproteinases. Dev. Neurosci. 2009, 31, 394-402. [CrossRef] [PubMed]

74. Hayakawa, K.; Okazaki, R.; Morioka, K.; Nakamura, K.; Tanaka, S.; Ogata, T. Lipopolysaccharide preconditioning facilitates M2 activation of resident microglia after spinal cord injury. J. Neurosci. Res. 2014, 92, 1647-1658. [CrossRef] [PubMed]

75. Saad, M.A.; Abdelsalam, R.M.; Kenawy, S.A.; Attia, A.S. Ischemic preconditioning and postconditioning alleviates hippocampal tissue damage through abrogation of apoptosis modulated by oxidative stress and inflammation during transient global cerebral ischemia-reperfusion in rats. Chem. Biol. Interact. 2015, 232, 21-29. [CrossRef] [PubMed]

76. Parmar, J.; Jones, N.M. Hypoxic preconditioning can reduce injury-induced inflammatory processes in the neonatal rat brain. Int. J. Dev. Neurosci. 2015, 43, 35-42. [CrossRef] [PubMed] 
77. Heusch, G. Cardioprotection: Chances and challenges of its translation to the clinic. Lancet 2013, 381, 166-175. [CrossRef]

78. Hausenloy, D.J.; Yellon, D.M. Ischaemic conditioning and reperfusion injury. Nat. Rev. Cardiol. 2016, 13, 193-209. [CrossRef] [PubMed]

79. Robertson, N.J.; Tan, S.; Groenendaal, F.; van Bel, F.; Juul, S.E.; Bennet, L.; Derrick, M.; Back, S.A.; Valdez, R.C.; Northington, F; et al. Which neuroprotective agents are ready for bench to bedside translation in the newborn infant? J. Pediatr. 2012, 160, 544-552. [CrossRef] [PubMed]

80. Livak, K.J.; Schmittgen, T.D. Analysis of relative gene expression data using real-time quantitative PCR and the 2(-Delta Delta C(T)) Method. Methods 2001, 25, 402-408. [CrossRef] [PubMed] article distributed under the terms and conditions of the Creative Commons Attribution (CC-BY) license (http://creativecommons.org/licenses/by/4.0/). 